\title{
Aerosol chemistry above an extended archipelago of the eastern Mediterranean basin during strong northern winds
}

\author{
E. Athanasopoulou ${ }^{1,2}$, A. P. Protonotariou ${ }^{2}$, E. Bossioli ${ }^{2}$, A. Dandou ${ }^{2}$, M. Tombrou ${ }^{2}$, J. D. Allan ${ }^{1,3}$, H. Coe ${ }^{1}$, \\ N. Mihalopoulos ${ }^{4,5}$, J. Kalogiros ${ }^{4}$, A. Bacak ${ }^{1}$, J. Sciare ${ }^{6,7}$, and G. Biskos ${ }^{7,8,9}$ \\ ${ }^{1}$ School of Earth, Atmosphere and Environmental Sciences, University of Manchester, Manchester, M13 9PL, UK \\ ${ }^{2}$ Department of Applied Physics, National and Kapodistrian University of Athens, 15784 Athens, Greece \\ ${ }^{3}$ National Centre for Atmospheric Science, University of Manchester, Manchester, M13 9PL, UK \\ ${ }^{4}$ Institute for Environmental Research and Sustainable Development, National Observatory of Athens, 15236 Athens, Greece \\ ${ }^{5}$ Chemistry department, University of Crete, 71003 Heraklion, Crete, Greece \\ ${ }^{6}$ Laboratoire des Sciences du Climat et de l'Environnement, LSCE, UMR8212, CNRS-CEA-UVSQ, \\ 91191 Gif-sur-Yvette, France \\ ${ }^{7}$ Energy Environment and Water Research Center, The Cyprus Institute, Nicosia, Cyprus \\ ${ }^{8}$ Department of Environment, University of Aegean, 81100 Mytilene, Greece \\ ${ }^{9}$ Faculty of Civil Engineering and Geosciences, Delft University of Technology, Delft, the Netherlands
}

Correspondence to: E. Athanasopoulou (eathana@phys.uoa.gr)

Received: 4 February 2015 - Published in Atmos. Chem. Phys. Discuss.: 27 March 2015

Revised: 25 May 2015 - Accepted: 29 June 2015 - Published: 28 July 2015

\begin{abstract}
Detailed aerosol chemical predictions by a comprehensive model system (i.e. PMCAMx, WRF, GEOSCHEM), along with airborne and ground-based observations, are presented and analysed over a wide domain covering the Aegean Archipelago. The studied period is 10 successive days in 2011, characterized by strong northern winds, which is the most frequently prevailing synoptic pattern during summer. The submicron aerosol load in the lower troposphere above the archipelago is homogenously enriched in sulfate (average modelled and measured submicron sulfate of 5.5 and $5.8 \mu \mathrm{g} \mathrm{m}^{-3}$, respectively), followed by organics (2.3 and $4.4 \mu \mathrm{g} \mathrm{m}^{-3}$ ) and ammonium (1.5 and $1.7 \mu \mathrm{g} \mathrm{m}^{-3}$ ). Aerosol concentrations smoothly decline aloft, reaching lower values $\left(<1 \mu \mathrm{g} \mathrm{m}^{-3}\right)$ above $4.2 \mathrm{~km}$ altitude. The evaluation criteria rate the model results for sulfate, ammonium, chloride, elemental carbon, organic carbon and total $\mathrm{PM}_{10}$ mass concentrations as "good", indicating a satisfactory representation of the aerosol chemistry and precursors. Higher model discrepancies are confined to the highest (e.g. peak sulfate values) and lowest ends (e.g. nitrate) of the airborne aerosol mass size distribution, as well as in airborne organic aerosol concentrations (model underestimation ca. $50 \%$ ). The latter is most likely related to the in-
\end{abstract}

tense fire activity at the eastern Balkan area and the Black Sea coastline, which is not represented in the current model application. The investigation of the effect of local variables on model performance revealed that the best agreement between predictions and observations occurs during high winds from the northeast, as well as for the area confined above the archipelago and up to $2.2 \mathrm{~km}$ altitude. The atmospheric ageing of biogenic particles is suggested to be activated in the aerosol chemistry module, when treating organics in a sufficient nitrogen and sulfate-rich environment, such as that over the Aegean basin. More than $70 \%$ of the predicted aerosol mass over the Aegean Archipelago during a representative Etesian episode is related to transport of aerosols and their precursors from outside the modelling domain.

\section{Introduction}

The geographical characteristics, specific atmospheric conditions and large range of natural and anthropogenic sources in the Mediterranean basin create a complex environmental situation contributing to the aerosol load. The major motivations for characterizing aerosols in the Mediterranean are 
their subsequent climate forcing (Nabat et al., 2014), as well as relevant air quality and health issues (Rodríguez et al., 2002; Medina et al., 2004). During summertime, regional circulation phenomena and increased photochemistry favour the accumulation and secondary formation of atmospheric aerosols (Millán et al., 1997; Rodríguez et al., 2002; Pey et al., 2013). The atmosphere over the Aegean Archipelago (also referred to as the Aegean Sea), part of the eastern Mediterranean (EM), is frequently affected by strong northern winds during the warm period. These winds are often bound to the Etesian flow (Maheras, 1986; Kotroni et al., 2001; Tylris and Lelieveld, 2013; Anagnostopoulou et al., 2014), which is the most common synoptic situation over the Aegean Sea (AS) during summer, transporting dry and cool air masses downwind of southern Russia, Ukraine, central/eastern Europe, the Balkan states and Turkey (Vrekoussis et al., 2005; Bryant et al., 2006; Sciare et al., 2008). The emissions from biomass burning and important urban and industrial centres situated in these regions, combined with the intense photochemical ageing of the arriving plumes and the decreased deposition of species in the marine environment, make the atmosphere above the AS a favourable area for aerosol investigation, particularly during regional-range transport phenomena observed in summer.

Previous aerosol modelling studies covering the AS (Lazaridis et al., 2005; Fountoukis et al., 2011; Im et al., 2012) have shown the predominance of non sea-salt sulfate in the fine aerosol mode, in agreement with previous groundbased observations (Mihalopoulos et al., 1997; Bardouki et al., 2003; Kanakidou et al., 2011), unlike anywhere else in Europe. Together with the high degree of oxidation of the organic matter (Hildebrandt et al., 2010), these findings are both consistent with the atmospheric conditions stated above. In addition, the important role of natural aerosol sources (seasalt production and long-range transported dust plumes) has been investigated, not only on the total $\mathrm{PM}_{10}$ mass levels (particulate matter with aerodynamic diameter $<10 \mu \mathrm{m}$ ) and on model performance, but also on the gas-aerosol interactions towards the modification of inorganic aerosol composition (Kallos et al., 2007; Astitha and Kallos, 2008; Athanasopoulou et al., 2008; Im, 2013). Another common output of model applications over this archipelago is the exogenous influence (short-, medium- and long-range transport) on aerosol chemical composition, $\mathrm{PM}_{10}$ concentration levels (European limit exceedances) and regional climate, in comparison with the contribution of local sources (Lazaridis et al., 2005; Kallos et al., 2007; Im and Kanakidou, 2012).

The relation between meteorology and aerosol load over the EM is less understood, and it has only been until recently that people have started studying it using atmospheric models. Im et al. (2012) and Megaritis et al. (2013) have studied the influence of temperature increases of up to $5 \mathrm{~K}$ on the chemical composition of aerosol particles. Their results are contradictory for sulfate (negative and positive changes in mass concentrations, respectively), but they are in agree- ment for nitrate (decrease in mass concentrations) and organics (increase in mass concentrations). Inversely, the effect of aerosols on regional climate has been investigated by Solomos et al. (2011) and Kallos et al. (2014), who showed that the properties of atmospheric particles can modify cloud structure and precipitation during a heavy rainfall event over the EM. Given the complexity of the aerosol mixture in the Mediterranean basin, further studies on the chemical characterization and size distribution of the aerosol mass will elucidate the interactions between airborne particles, meteorology and climate in the region.

A satisfactory representation of aerosol chemical species by model applications is a challenging task. Predictions over the AS from the aforementioned studies have been evaluated against concurrent or past measurements (Chabas and Lefevre, 2000; Kouvarakis et al., 2001; Smolik et al., 2003; Eleftheriadis et al., 2006; Gerasopoulos et al., 2006, 2007; Sciare et al., 2003, 2008; Koulouri et al., 2008; Pikridas et al., 2010; Im et al., 2012). Comparisons showed a moderate to large underestimation of the simulated $\mathrm{PM}_{10}$ (Lazaridis et al., 2005; Im and Kanakidou, 2012) or organic mass concentration (Fountoukis et al., 2011), despite inorganic species being well represented (Astitha and Kallos, 2008; Athanasopoulou et al., 2008; Fountoukis et al., 2011). Improved model performance for precipitation is achieved when cloud condensation nuclei activation of aerosols is included (Kallos et al., 2014).

Most of the above modelling studies focus on the surface representation of aerosols and are compared against groundbased observational data from the station of Finokalia in Crete (south AS). A few modelling studies that investigated the vertical profiles of dust and sea-salt aerosols found that particles over the EM did not elevate higher than $2 \mathrm{~km}$ (Astitha and Kallos, 2008; Solomos et al., 2011). The latter study, which was compared against airborne measurements conducted near the Israeli coast, showed a good correlation between modelled and airborne measurements of aerosol mass concentrations. An earlier airborne experiment over the Aegean Archipelago (not bound to a regional model application), showed that the atmosphere $3.5 \mathrm{~km}$ above sea level (a.s.l.) is almost completely depleted of particles during Etesians (Formenti et al., 2002). This study also confirmed that additional quantities of aged aerosols from fossil fuel combustion and forest fires are transported southward. Recently, four clustered airborne campaigns, performed during a 10day period of strong northern winds (including Etesians), provided amongst others a unique data set, including measurements of the chemical composition of submicron particles above the AS and western Turkey. The first results from these measurements are selectively presented in Bezantakos et al. (2013) and Tombrou et al. $(2013,2015)$.

The present study provides predictions of the size distribution and the chemical composition of aerosol particles observed over the wider region of the Aegean Archipelago during the same 10-day period (August-September 2011), taking full advantage of the aforementioned airborne data 
set and supportive ground-based aerosol observations. In order to capture the airflows over the Aegean basin more efficiently, a comprehensive coupling of gases and aerosols between the PMCAMx and GEOS-CHEM chemical transport models (CTM) is performed and applied here for the first time. Outputs from the PMCAMx model are compared against the complete set of experimental aerosol data, providing the most extensive evaluation of aerosol simulation performances over a wide region of the Mediterranean basin. The large number of prediction-observation pairs enables the investigation of the parameters that significantly affect aerosol model performance. An inter-comparison among different scenarios is performed with respect to the airborne observations, in order to improve predictions of the organic aerosol fraction in the marine environment. This combined use of CTMs and monitoring data, which is emphasized by the latest European air quality directive, is taking advantage of the capabilities of the applied model system. The current model applications presented here complement the newly existing aerosol data set regarding the origin and chemical ageing of the organic matter (primary, oxygenated, anthropogenic and biogenic), the chemical composition and particle size distribution and the role of non-local sources of air pollution on the mass of each aerosol species under different paths of northern transport.

\section{Experimental data}

\subsection{Airborne measurements}

Airborne data from four EUFAR (http://www.eufar.net/) campaigns (i.e. AEGEAN-GAME, ACEMED, CarbonExp and CIMS) are utilized in this study. The measurements were conducted using the UK BAe-146-301 Atmospheric Research Aircraft, which was operated through the Facility for Airborne Atmospheric Measurements (FAAM, http: //www.faam.ac.uk/). Nine flights were performed between 31 August and 09 September 2011 (cf. Fig. 1). In all flights, the aircraft took off from and landed at the airport of Chania in northwest (NW) Crete. Five of the flights passed over the AS (on 1, 2, 4, and 7 September), one oriented towards Thessaloniki passing over Athens (8 September), while the aircraft flew over the western coast of Turkey up to the southwest (SW) coast of the Black Sea during the rest of the flights. With the exception of the last flight on 8 September, all flights were performed from 08:00 to 15:00 UTC. Flight paths in the Greek airspace were at altitudes up to $5 \mathrm{~km}$ a.s.l., while those over Turkey were above 2 and up to $7.6 \mathrm{~km}$ a.s.l.

The airborne measurements during these campaigns provided, among other atmospheric parameters, the chemical composition of aerosols. High-time resolution measurements of the sulfate $\left(\mathrm{SO}_{4}^{2-}\right)$, nitrate $\left(\mathrm{NO}_{3}^{-}\right)$, ammonium $\left(\mathrm{NH}_{4}^{+}\right)$, chloride $\left(\mathrm{Cl}^{-}\right)$and organic $(\mathrm{OA})$ content of the submicron particles $\left(\mathrm{PM}_{1}\right)$ were performed by an airborne com- pact time-of-flight aerosol mass spectrometer (cToF-AMS) (Canagaratna et al., 2007; Morgan et al., 2010). Aerosol mass concentrations are reported at ambient temperature and pressure (i.e. a conversion from standard temperature and pressure to ambient conditions has been applied). In common with other AMS measurements, these measurements nominally represent the submicron, non-refractory component of the aerosols, therefore do not include any sulfate, nitrate or chloride associated with sea salt or dust particles. The collection efficiency (CE) was estimated based on the parameterization described by Middlebrook et al. (2012), which was close to unity based on the acidic nature of the particles. Because no on-board validation of this chemical data was available (no other composition data were obtained and the possible presence of sea salt particles would confound a comparison with the particle sizing instruments), it is prudent to assign an uncertainty of ca. 30-35\% to the AMS measurements, as suggested by Bahreini et al. (2009).

Wind speed and direction, air temperature and water vapour mixing ratio were also available and used here for model evaluation (Sect. 4.1). More information on the flights, instrumentation and measured data during this period can be found in Bezantakos et al. (2013) and Tombrou et al. (2015).

\subsection{Ground measurements}

Ground-based measurements of the chemical composition and physical properties of the particles in the region were conducted at two remote stations located at Vigla $\left(39^{\circ} 58^{\prime} \mathrm{N}\right.$, $25^{\circ} 04^{\prime} \mathrm{E}$; $420 \mathrm{~m}$ a.s.l.) on the island of Lemnos and Finokalia, $\left(35^{\circ} 20^{\prime} \mathrm{N}, 25^{\circ} 40^{\prime} \mathrm{E} ; 150 \mathrm{~m}\right.$ a.s.l.) on the island of Crete, between 29 August and 09 September 2011. Both sites are far from major cities and local anthropogenic sources (Fig. 1a). To determine the aerosol chemical composition observed at Vigla and Finokalia, particles were collected every 1,6 or $8 \mathrm{~h}$ using $\mathrm{PM}_{10}$ and $\mathrm{PM}_{1}$ samplers. The ground aerosol data used in this study are the $\mathrm{PM}_{10}$ elemental (EC) and organic carbon (OC) (6h samples), the $\mathrm{PM}_{1} \mathrm{SO}_{4}^{2-}$ (hourly samples) and the total $\mathrm{PM}_{10}$ mass ( $8 \mathrm{~h}$ samples).

$\mathrm{OC}$ and EC concentrations on the collected samples were measured with a Sunset lab instrument (Sunset Laboratory Inc.; OR, USA) implemented with the EUSAAR-2 protocol (Cavalli et al., 2010). Analytical procedures and detection limits of the methods are reported in detail by Paraskevopoulou et al. (2014). Finally, measurements of anions in $\mathrm{PM}_{1}$ were performed at Finokalia using a particleinto-liquid sampler (PILS) (Orsini et al., 2003) running at $15.5 \mathrm{~L} \mathrm{~min}^{-1}$ and coupled with an ion chromatograph (IC). More information on the PILS-IC settings used here is available in Sciare et al. (2011).

Wind speed, wind direction, as well as the concentrations of ozone $\left(\mathrm{O}_{3}\right)$ and nitrogen oxides $\left(\mathrm{NO}_{x}: \mathrm{NO}+\mathrm{NO}_{2}\right)$ measured at the Finokalia station are also used herein (cf. Sect. 4.1). 

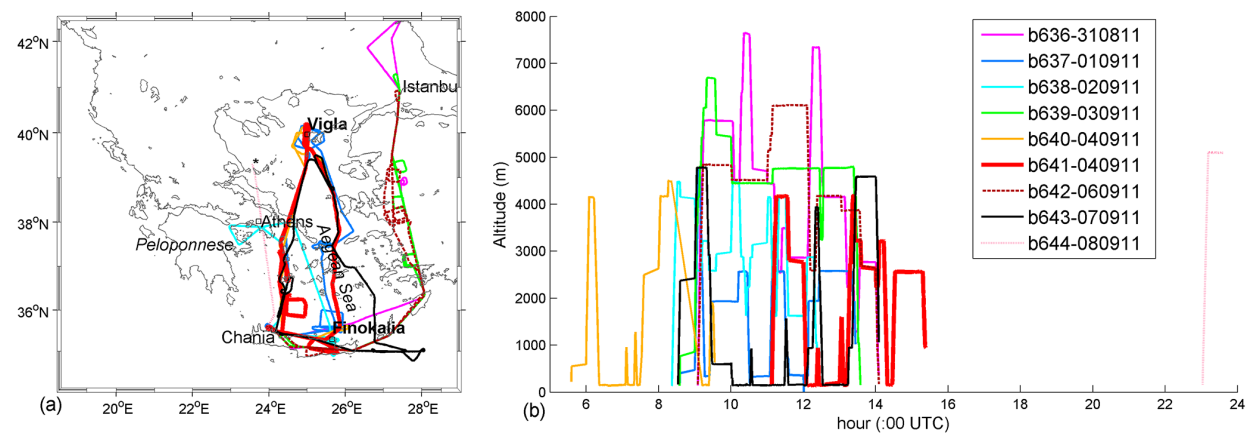

Figure 1. (a) Geographical map of the PMCAMx model domain covering the greater area of the Aegean Sea, showing also the trajectories for the nine flights during the modelling period (29 August-09 September 2011). All flights took off and landed at the airport of Chania. The aircraft over the Aegean Sea moved anti-clockwise. The ground monitoring sites are indicated by the bold fonts. The rest indicate areas discussed within the text. (b) The aircraft altitude during the time frame of each flight.

\section{Methodology}

\subsection{Model framework}

The model system used in this study is comprised of the regional aerosol model PMCAMx, the regional meteorological model WRF/ARW (hereafter referred as WRF, Skamarock et al., 2008) and the global chemistry transport model GEOSCHEM (Bey et al., 2001), following the methodology described by Tombrou et al. (2009). The setup of the modelsis given in Table 1 and Sect. S1 in the Supplement. All air quality model results presented in this study correspond to the PMCAMx runs.

PMCAMx is the research version of a former version (v.4) of the publicly available 3-D, Eulerian chemical transport model CAMx (ENVIRON, 2003). Aerosols therein, are represented by a detailed chemical composition: potassium $\left(\mathrm{K}^{+}\right)$, calcium $\left(\mathrm{Ca}^{2+}\right)$, magnesium $\left(\mathrm{Mg}^{2+}\right), \mathrm{NH}_{4}^{+}$, sodium $\left(\mathrm{Na}^{+}\right), \mathrm{SO}_{4}^{2-}, \mathrm{NO}_{3}, \mathrm{Cl}^{-}$, water $\left(\mathrm{H}_{2} \mathrm{O}\right), \mathrm{EC}$, reactive and inert primary organic aerosols (APO and POA, respectively), oxidized APO (AOO) and secondary organic aerosols of anthropogenic (ASOA) and biogenic (BSOA) origin. All these species are distributed over 10 discrete and internally mixed size sections, in the diameter range of 0.04 to $40 \mu \mathrm{m}$ (cut-off diameters: $0.04,0.08,0.1,0.3,0.6,1.2,2.5,5,10,20,40 \mu \mathrm{m}$ ). This chemical and size treatment results in 400 aerosol model components in total.

The aerosol-related dynamical processes considered in PMCAMx include primary emissions, new particle formation by nucleation, condensation, evaporation, wet and dry deposition, coagulation and chemistry. The incorporated chemical modules are shown in Table 1 . The ageing rate constants for primary and secondary organic aerosols (both anthropogenic and biogenic) are $4 \times 10^{-11}$ and $1 \times 10^{-11} \mathrm{~cm}^{3} \mathrm{~mol}^{-1} \mathrm{~s}^{-1}$, respectively (Murphy et al., 2011).

\subsection{Model coupling}

In the frame of this study, the two chemical models are coupled offline, so that GEOS-CHEM provides concentrations for a series of species at the boundaries (lateral and top; boundary conditions - BCs) of the PMCAMx domain for each hour of the simulation period. A three-dimensional initialization field (29 August 2011, 00:00 Local Standard Time; LST) is also extracted from GEOS-CHEM and used by PMCAMx (ICs). Differences in the chemistry and spatial resolution used by the two models demanded a chemical and three-dimensional matching between the two models with respect to the gas and aerosol fields. The chemical linking between the two air quality models (Table 2 ) involves 41 gaseous species ( 20 of which are VOCs) and 63 aerosol species $\left(\mathrm{SO}_{4}^{2-}, \mathrm{NO}_{3}^{-}, \mathrm{NH}_{4}^{+}\right.$, APO, ASOA, BSOA, $\mathrm{EC}, \mathrm{Na}^{+}, \mathrm{Cl}^{-}, \mathrm{Mg}^{2+}, \mathrm{Ca}^{2+}$ and others, distributed over the size bins treated by PMCAMx). A conversion factor of 2.1 was used to calculate total organic aerosols (OA) from the OC GEOS-CHEM outputs, of which value is suitable for non-urban areas (Turpin and Lim, 2001) and has already been reported in the literature for OA over Crete (Sciare et al., 2005; Hildbrandt et al., 2010). In order to assess the relative contribution of the different OA precursors to the total SOA transported from outside the PMCAMx modelling domain (GEOS-CHEM BCs), each of the five lumped SOA species treated by the volatility basis set (VBS) scheme in PMCAMx is coupled to each unique oxidative product treated by GEOS-CHEM (instead to that of the uniform distribution of their mixture, Sect. 4.3). Sea-salt and dust species treated by GEOS-CHEM are chemically resolved to the PMCAMx species following Athanasopoulou et al. (2008) and Kandler et al. (2007) respectively (cf. Table 2).

The hourly meteorological fields provided offline by the WRF to the PMCAMx, include horizontal wind speed, temperature, diffusion coefficients $\left(K_{v}\right)$, pressure and water vapour, cloud optical depth, cloud and precipitated water. $K_{v}$ values are calculated directly during the WRF run, and are 


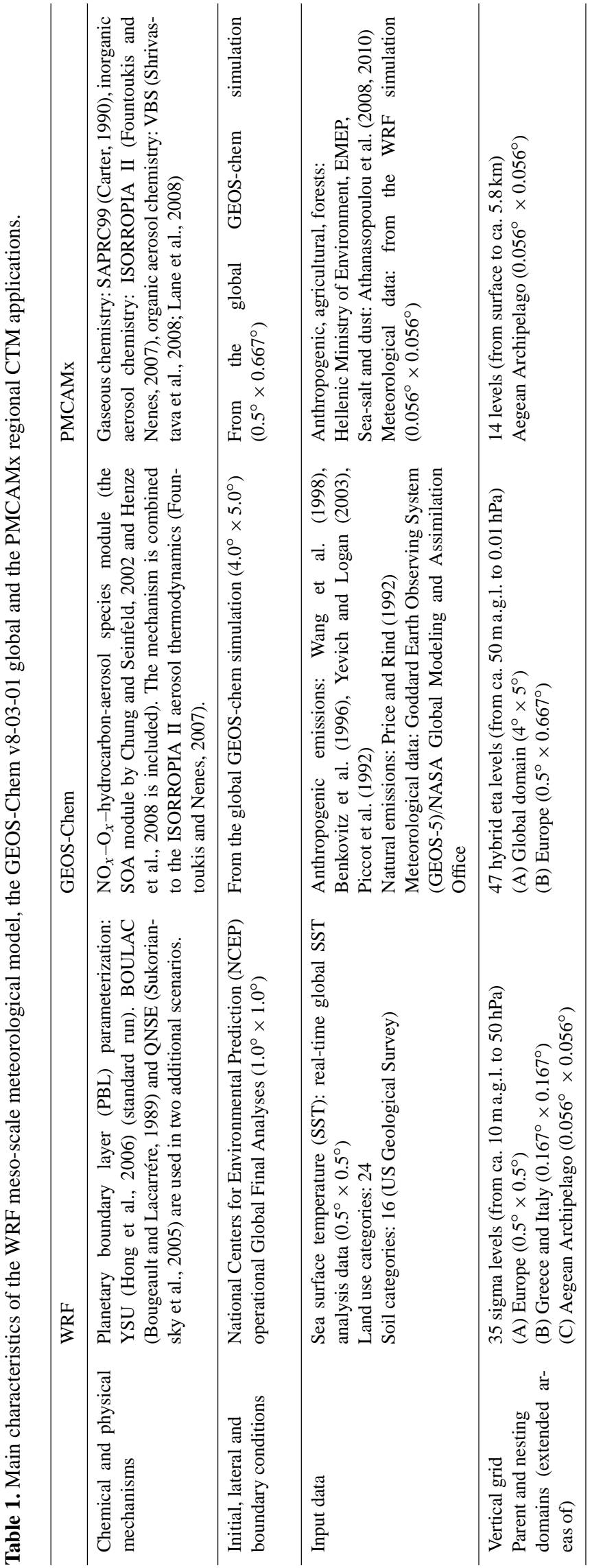

then adjusted for the heights under $100 \mathrm{~m}$, which is found to benefit air quality predictions (ENVIRON, 2011). Minimum $K_{v}$ value is set to $0.1 \mathrm{~m}^{2} \mathrm{~s}^{-1}$.

\subsection{Simulations setup}

The PMCAMx simulation domain is the greater area of the Aegean Archipelago (Fig. 1a; 34.1 to $42.5^{\circ} \mathrm{N}, 18.4$ to $29^{\circ} \mathrm{E}$ ) with $0.056^{\circ}(\sim 6.2 \mathrm{~km})$ horizontal grid resolution and 14 vertical layers with their domain-averaged layer top at 20.9, 29.3, 69.7, 129, 169, 228, 531, 869, 1256, 1696, 2166, 3252, 4496 and $575 \mathrm{~m}$ above ground level (a.g.l.). The simulations are realized during the period from 29 August to 09 September 2011 , so that they are directly comparable with measurements. Model outputs are extracted on hourly basis. The first 2 days are used as a spin-up.

Emissions from the anthropogenic, agricultural activities and forests used by the PMCAMx model for the area of Greece are based on a National database provided by the Ministry of Environment for the year 2002. The emission rates for the area of Turkey are retrieved from the EMEP emission data set (http://www.ceip.at/webdab-emission-database/ officially-reported-emission-data/). Analytical information on the setup for the WRF and GEOS-CHEM simulations, as well as on the emissions treated by the chemical models is given in the Supplement (Sect. S1).

The standard model application that provides the basecase outputs follows the modelling configuration described so far. The first applied scenario aims at investigating the exogenous aerosol fraction over the Aegean Archipelago (trans-boundary pollution). This is captured by the coupling between PMCAMx and GEOS-CHEM models and was identified through a combination of two simulations: the standard run (i.e. BCs provided by GEOS-CHEM) and a scenario with constant, minimum BCs (scenario 1). The different contribution to aerosol levels from sources in Greece and the Turkish area (covered by the simulation domain) is calculated by switching off the emissions from Turkey in scenario 1 (scenario 2) (Sects. 4.2 to 4.4 ).

To assess the sensitivity of organic aerosol simulation performance, a series of model scenarios was performed. Here, results on the OA sensitivity to their ageing process are presented, following previous model studies (Tsimpidi et al., 2010; Fountoukis et al., 2011): one scenario with the BSOA ageing switched off (scenario 3) and another with the ASOA ageing constant multiplied by 4 (scenario 4) (Sect. 4.3).

The sensitivity of simulated aerosol mass loading on modelled meteorology is also examined. Apart from the standard model setup, where WRF uses the YSU planetary boundary layer (PBL) parameterization (Table 1), two additional PMCAMx simulations were performed using WRF inputs from an application with the Bougeault-Lacarrère (BOULAC) PBL parameterization scheme (Bougeault and Lacarrère, 1989) (scenario 5) and with quasi-normal scale elimination 
Table 2. The chemical coupling (in ppb) between the PMCAMx (SAPRC, ISORROPIAII and VBS mechanisms) and the GEOS-CHEM (SOA mechanism) model. Aerosols are shown in bold. The numbers next to PMCAMx aerosol species correspond to their size bins. PM 2.5 in PMCAMx corresponds to the bins 1 to 6 , while the rest of the bins (7 to 10) are PM $_{2.5-40}$. Sea-salt aerosols (SSA) in GEOS-CHEM are simulated in two bins (effective diameter ranges 0.2 to 5 and 5 to $8 \mu \mathrm{m}$ ), while dust particles (DST) are split into 4 bins (effective diameters $1.4,2.8,4.8$ and $9 \mu \mathrm{m})$.

\begin{tabular}{|c|c|c|c|c|c|}
\hline No & PMCAMx & GEOS-CHEM & No & PMCAMx & GEOS-CHEM \\
\hline 1 & $\mathrm{NO}_{2}$ & $\mathrm{NO}_{X}$ & 30 & $\mathrm{SO}_{2}$ & $\mathrm{SO}_{2}$ \\
\hline 2 & $\mathrm{O}_{3}$ & $\mathrm{NO}_{X}-\mathrm{O}_{X}$ & 31 & Sulfuric acid (SULF) & SULF + methyl sulfonic acid \\
\hline 3 & Peroxyacetyl nitrate (PAN) & PAN & 32 & $\mathrm{NH}_{3}$ & $\mathrm{NH}_{3}$ \\
\hline 4 & Higher peroxyacetyl nitrate & $\begin{array}{l}\text { Lumped peroxypropionyl } \\
\text { nitrate }\end{array}$ & 33 & Hydrogen peroxide $\left(\mathrm{H}_{2} \mathrm{O}_{2}\right)$ & $\mathrm{H}_{2} \mathrm{O}_{2}$ \\
\hline 5 & PAN compound from methacrolein & Peroxymethacroyl nitrate & $34-37$ & $\begin{array}{l}\text { ASOA gaseous precursors } \\
(\mathrm{CAS} 1-4)\end{array}$ & Oxidized aromatics \\
\hline 6 & Organic nitrate & Lumped alkyl nitrate & 38 & $\begin{array}{l}\text { BSOA gaseous precursors } \\
\text { (CBS1) }\end{array}$ & $\begin{array}{l}\text { Oxidized a-pinene, b-pinene, } \\
\text { sabinene, carene, terpenoid ke- } \\
\text { tones, limonene, terpenes }\end{array}$ \\
\hline 7 & Peroxynitric acid $\left(\mathrm{HNO}_{4}\right)$ & $\mathrm{HNO}_{4}$ & 39 & $\begin{array}{l}\text { BSOA gaseous precursors } \\
(\mathrm{CBS} 2)\end{array}$ & $\begin{array}{l}\text { Oxidized myrcene, terpenoid } \\
\text { alcohols, ocimene }\end{array}$ \\
\hline 8 & Formaldehyde (HCHO) & $\mathrm{HCHO}$ & 40 & $\begin{array}{l}\text { BSOA gaseous precursors } \\
\text { (CBS3) }\end{array}$ & Oxidized sesquiterpenes \\
\hline 9 & Acetaldehyde (CCHO) & Acetaldehyde ALD2 & 41 & $\begin{array}{l}\text { BSOA gaseous precursors } \\
\text { (CBS4) }\end{array}$ & Oxidized isoprene \\
\hline 10 & Higher aldehyde (RCHO) & $\mathrm{RCHO}$ & 1-3 & APO4-6 & $\begin{array}{l}\text { Organic carbon } \\
\text { (OCPI+OCPO) }\end{array}$ \\
\hline 11 & Isoprene (ISOP) & $0.2 \mathrm{ISOP}$ & 4-7 & ASOA1-4 & Aerosol aromatics \\
\hline 12 & Methylvinyl ketone (MVK) & MVK & 8 & BSOA1 & aerosol a-pinene etc \\
\hline 13 & Methacrolein (METH) & Methacrolein (MACR) & 9 & BSOA2 & aerosol myrcene etc \\
\hline 14 & Terpene & $\begin{array}{l}\text { A-pinene, B-pinene, sabinene, } \\
\text { carene, terpenoid ketones, } \\
\text { limonene, myrcene, terpenoid } \\
\text { alcohols, ocimene }\end{array}$ & 10 & BSOA3 & aerosol sesquiterpenes \\
\hline 15 & $\mathrm{HNO}_{3}$ & $\mathrm{HNO}_{3}$ & 11 & BSOA4 & aerosol isoprene \\
\hline 16 & Acetone (ACET) & 0.3 ACET & $12-14$ & PEC4-6 & black carbon (BCPI+BCPO) \\
\hline 17 & Methylethyl ketone (MEK) & $0.3 \mathrm{MEK}$ & 15-20 & $\mathrm{NO}_{3} 4-9$ & $\mathbf{N O}_{3}+\mathbf{s s N O}_{3}+\mathbf{0 . 0 0 9} \mathbf{S S A}_{1-2}$ \\
\hline 18 & Methyl hydroperoxide (COOH) & Methyl hydroperoxide (MP) & 21-23 & $\mathrm{NH}_{4}$ 4-6 & NH4 \\
\hline 19 & $\mathrm{CO}$ & $\mathrm{CO}$ & 24-26 & $\mathrm{SO}_{4} 4-6$ & $\mathrm{SO}_{4}+0.25 \mathrm{sSSO}_{4}+\mathbf{0 . 0 3} \mathrm{SSA}_{1}$ \\
\hline 20 & Lumped alkanes 1 & 0.5 ethane & 27-29 & $\mathrm{SO}_{4} \mathbf{7 - 9}$ & $0.75 \mathrm{ssSO}_{4}+0.03 \mathrm{SSA}_{2}$ \\
\hline 21 & Lumped alkanes 2 & 0.33 propane & 30-35 & Cl 4-9 & 0.42 $\mathrm{SSA}_{1-2}+\mathbf{0 . 0 1} \mathrm{DST}_{1-4}$ \\
\hline 22 & Lumped alkanes 3 & 0.09 lumped alkanes & 36-38 & $\mathrm{Na} 4-6$ & $0.46 \mathrm{SSA}_{f 1}+\mathbf{0 . 0 5} \mathrm{DST}_{1-2}$ \\
\hline 23 & Lumped alkanes 4 & 0.09 lumped alkanes & $39-41$ & Na 7-9 & $0.46 \mathrm{SSA}_{2}+0.04 \mathrm{DST}_{3-4}$ \\
\hline 24 & Lumped alkanes 5 & 0.09 lumped alkanes & $42-44$ & Ca 4-6 & 0.009 $\mathbf{S S A}_{1}+\mathbf{0 . 0 7} \mathbf{D S T}_{1-2}$ \\
\hline 25 & Lumped aromatics 1 & 0.16 benzene +0.14 toluene & $45-47$ & Ca 7-9 & $\mathbf{0 . 0 4}^{\mathrm{DST}_{3-4}}$ \\
\hline 26 & Lumped aromatics 2 & 0.13 xylene & $48-53$ & K 4-9 & 0.009 SSA $_{1-2}+\mathbf{0 . 0 3}$ DST $_{1-4}$ \\
\hline 27 & Lumped olefins 1 & 0.17 lumped alkenes & $54-59$ & Mg 4-9 & 0.06 $\mathbf{S S A}_{1-2}+\mathbf{0 . 0 5} \mathbf{D S T}_{1-4}$ \\
\hline 28 & Lumped olefins 2 & 0.17 lumped alkenes & 60 & Si, Al (CRST6) & 0.81 DST $_{1-2}$ \\
\hline 29 & $\mathrm{~N}_{X} \mathrm{O}_{Y}$ & $\mathrm{~N}_{2} \mathrm{O}_{5}$ & $61-63$ & Si, Al (CRST 7-9) & 0.83 $\mathrm{DST}_{3-4}$ \\
\hline
\end{tabular}

(QNSE) (Sukoriansky et al., 2005) (scenario 6). This selection was based on wind speed differences between seven different PBL schemes (Dandou et al., 2014) (Sects. 4.2 to 4.3).

In order to compare predicted versus measured nitrate aerosol fractions (i.e. using the AMS data), a sea-salt aerosols-free case was applied (scenario 7) (Sect. 4.5). A summary of all model applications is given in Table 3.

\subsection{Model evaluation statistics}

Aerosol predictions are compared against AMS measurements using the statistical measures of mean bias (MB) and error (ME), mean fractional bias (MFB) and error (MFE), normalized mean bias (NMB) and error (NME), root mean square error (RMSE) and correlation coefficient $\left(r\right.$ and $\left.r^{2}\right)$.
The formulas of these indices are given in Table S2 in the Supplement. The airborne observational data that fall within a computational cell during a model time step (hour) are averaged, in order to be directly comparable with the model outputs.

In order to estimate which parameters systematically affect the model discrepancies, a multiple linear regression was used for each aerosol species among the model biases and basic, local variables (e.g. co-ordinates, day/flight, time, wind speed and wind direction). Based on the regression results, paired samples were created between the model biases and each parameter that significantly affects them (e.g. the model biases and the observed wind speeds were paired and formed one sample). 
Table 3. Description of the modelling scenarios performed by the PMCAMx model during 29 August-09 September 2011.

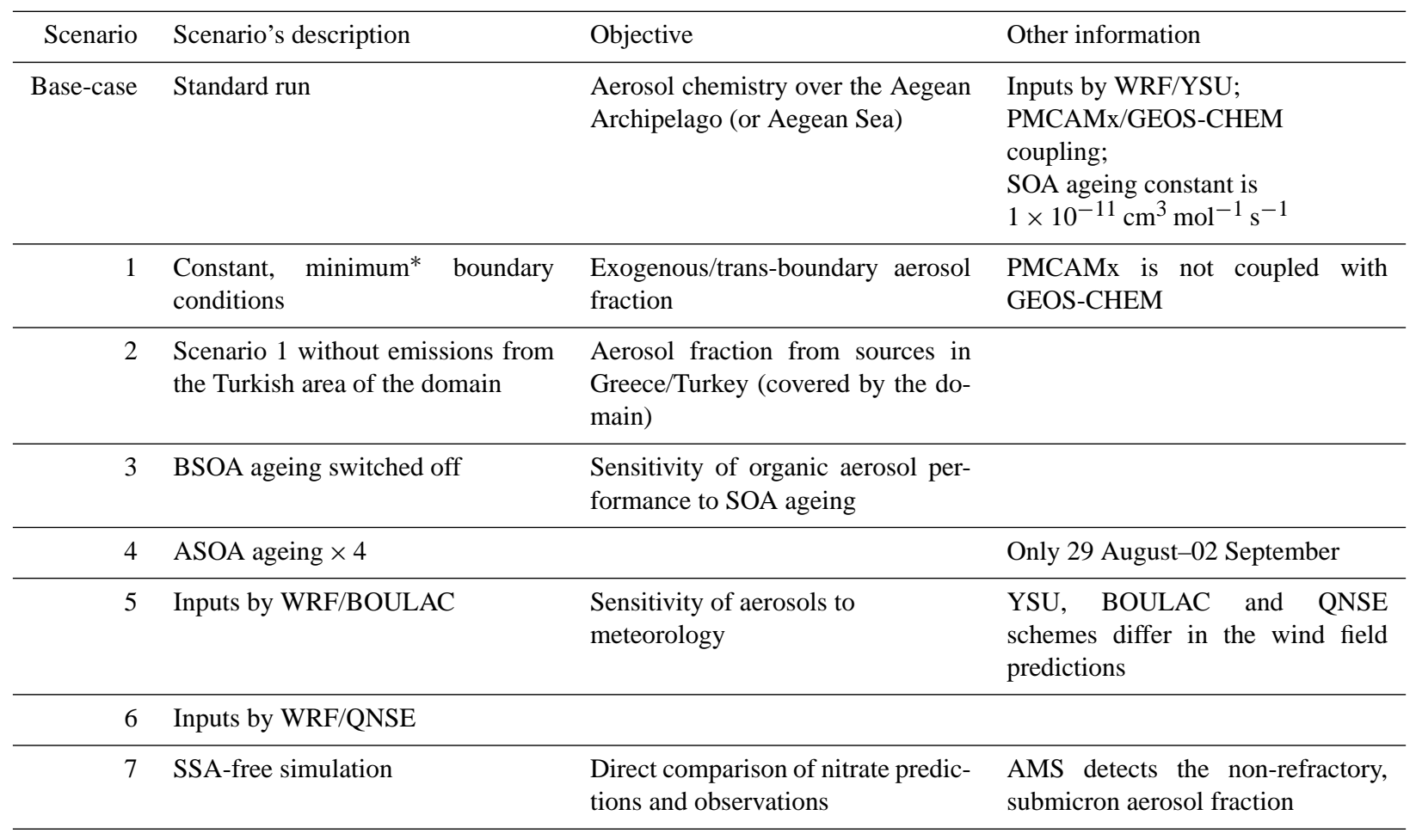

* aerosol species concentrations are equal to $10^{-9} \mu \mathrm{g} \mathrm{m}^{-3}$

Each of these paired samples were subdivided into two samples, on the basis of thresholds considering the model performance; i.e. the threshold is set for the parameter value where performance goals are met (or not) for the $\sim 75 \%$ of the predicted values of the one (or the other) sub-sample. In particular, the threshold regarding altitude is estimated to be at $2.2 \mathrm{~km}$, close to the PBL height over the domain. Other thresholds set for the paired samples are the longitude of $27^{\circ}$ that separates the Aegean Sea from Turkey, the 0-degree winds that divide NW from NE (northeast) sectors and the wind speed of $9 \mathrm{~ms}^{-1}$. The statistical hypothesis tests $(F$ and $t$ tests) confirmed that for all cases, the two sub-samples were significantly different from each other. This procedure specified under which conditions (e.g. wind speed values and direction) aerosol model performance over the AS is systematically good or poor and is presented in Sects. 4.2 to 4.4 .

\section{Results and discussion}

The following sections analyse the model results with respect to the measurements. In parallel, measurement findings are supported by the capabilities of the current model system. Model outputs are thoroughly evaluated against airborne AMS and ground-based observations. MFB and MFE were selected as the most appropriate metrics to summarize aerosol model (PMCAMx) performance (Boylan and Rus- sell, 2006). The calculated values are compared against the proposed goals and criteria for each aerosol species (Table S2), in order to characterize model performance as good (the level of accuracy that is considered to be close to the best a model can be expected to achieve) or average (the level of accuracy that is considered to be acceptable for modelling applications). When the standards are not met for one or more species, the model skills (with regard to these species) are characterized as poor, and the reasons for the model discrepancies are further investigated.

The WRF model was evaluated following the modelevaluation benchmarks suggested by Tesche et al. (2001) and Emery et al. (2001). In particular, mean absolute gross error (MAGE), MB, RMSE and index of agreement (IA) are compared against the proposed benchmark values (Table S2).

\subsection{Meteorology and gas-phase chemistry}

Strong northerly winds dominated during the simulated period, as also shown by Tombrou et al. (2015). In most cases, both the predicted and the observed winds were NE and NW, which seems to depend on the latitude. Nevertheless, local surface winds observed at the site of Finokalia exhibit a strong westerly component (Fig. S1a). This pattern is attributed to the effect of local topography, while predictions reflect a representative value of a grid cell (an area of $\sim 38 \mathrm{~km}^{2}$ ), mainly covered by sea. 

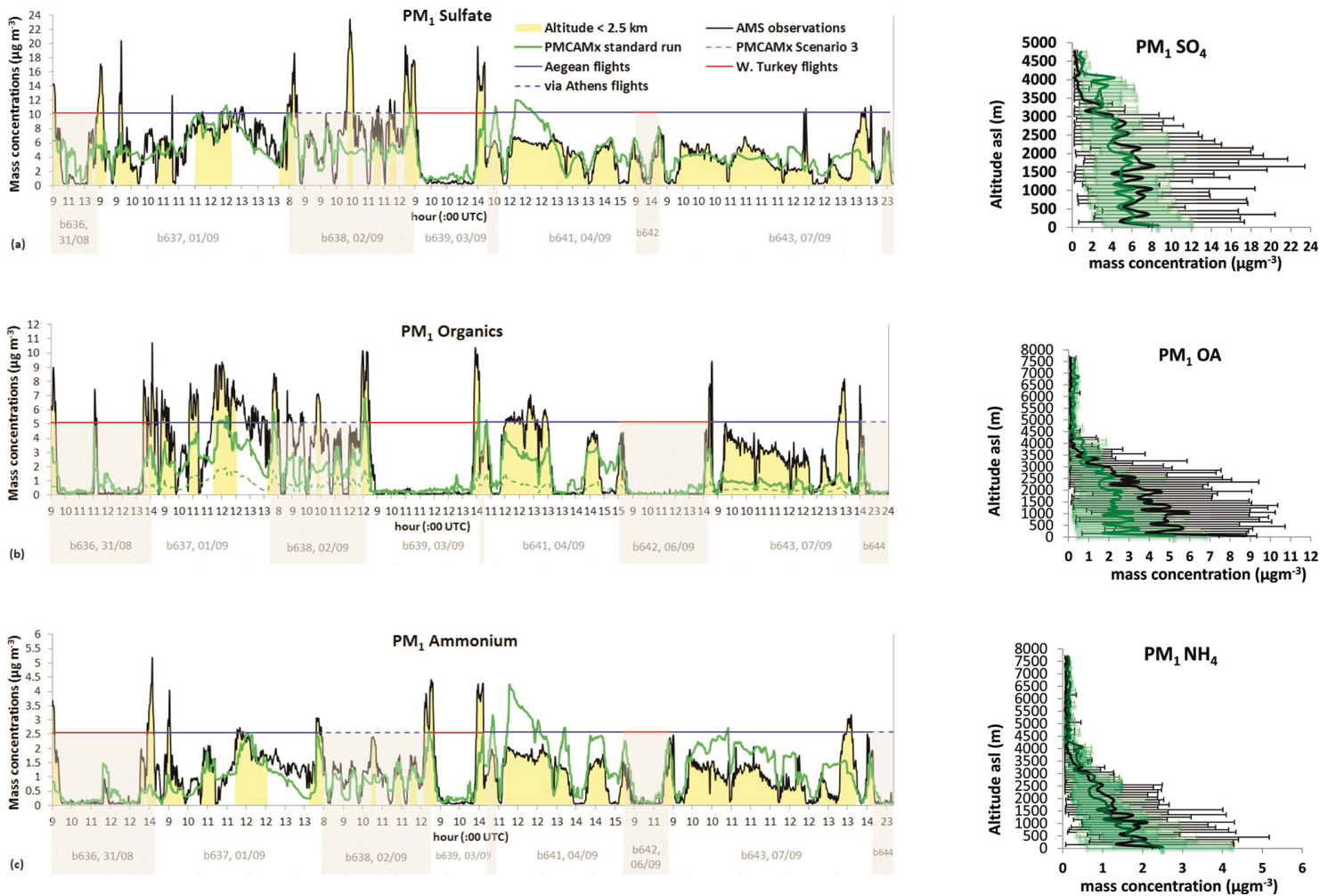

Figure 2. Comparison of PMCAMx results (green continuous line) with AMS airborne measurements (black continuous line) for total PM : $^{\circ}$ (a) sulfate; the legend applies for all succeeding graphs, (b) organics (green dashed line for scenario 3 is also shown), (c) hourly particulate ammonium concentrations $\left(\mu \mathrm{g} \mathrm{m}^{-3}\right.$ ) for all flights in the frame of the AEGEAN-GAME, ACEMED, CarbonExp and CIMS campaigns, during 31 August-09 September 2011. Data from the flights over the Aegean Sea, via Athens and over west Turkey are discriminated by the horizontal blue, dashed-blue and red lines, respectively. The yellow shaded area indicates mass concentrations below $2.2 \mathrm{~km}$ a.s.l. The flight numbers and dates are shown at the bottom. More detailed flight information is embedded in Fig. 1. On the right of each graph, the vertical profile of each species averaged per $100 \mathrm{~m}$ (error bars with minimum and maximum values) is shown.

An overall good agreement is found between the airborne measured and simulated values over the archipelago, as far as humidity, air temperature and wind direction are concerned (cf. Table S3). Regarding wind speed, model performance is weaker (two out of the three proposed benchmarks are reached, as shown in Table S2). The predicted mean value $\left(8.0 \mathrm{~m} \mathrm{~s}^{-1}\right)$ along all flight tracks is in good agreement with the measured one $\left(8.4 \mathrm{~m} \mathrm{~s}^{-1}\right.$; Table S3). More specifically, the average (maximum) predicted value was 9.0 (16.5) and $7.5(19.5) \mathrm{m} \mathrm{s}^{-1}$ upon the flight tracks below and above $2.2 \mathrm{~km}$ a.s.l., respectively. The corresponding measured wind speeds were 9.7 (22.4) and $7.8(24.1) \mathrm{m} \mathrm{s}^{-1}$. As far as the surface-wind speed (at $10 \mathrm{ma.g} .1$.) is concerned, the 9-day average (minimum to maximum) surface wind speed predictions at Finokalia were 7.5 (3.0 to 10.7) $\mathrm{m} \mathrm{s}^{-1}$, while the respective measurements were 6.8 (1.1 to 9.1$) \mathrm{m} \mathrm{s}^{-1}$. The different scale between point measurements and model results, which represent volume averages, contributes to this divergence.

Fourth and seventh September 2011 were typical Etesian days with strong-channelled northeasterly surface winds
(>15 $\mathrm{m} \mathrm{s}^{-1}$ ) over the archipelago (Tyrlis and Lelieveld, 2012). Under such conditions, the afternoon marine atmospheric boundary layer was around 1000,700 and $500 \mathrm{~m}$ in the north, SW and SE (southeast) Aegean, respectively, successfully represented by the PBL schemes used in this study (Tombrou et al., 2015; Dandou et al., 2014).

Gas-phase comparisons between PMCAMx and ground concentration measurements do not exhibit any significant inconsistencies. The 12-day average (minimum to maximum) $\mathrm{NO}_{x}$ and $\mathrm{O}_{3}$ predictions at Finokalia were $0.4(0.1$ to 2.8 ) and 62 (42 to 72) ppbv, while the respective measurements were 0.5 ( 0 to 1.4 ) and 66 (41 to 89 ) ppbv. The temporal correlation between predictions and measurements is also good, i.e. NME of the hourly data series is 55 and $10 \%$, respectively (Fig. S1b and c in the Supplement).

Overall, the aerosol model performance during the studied period is independent of any systematic and important meteorological and/or gaseous inconsistencies. 


\subsection{Sulfate aerosols $\left(\mathrm{PM}_{1} \mathrm{SO}_{4}\right)$}

\subsubsection{Model evaluation}

Figure 2a shows all available prediction-observation pairs of the airborne $\mathrm{PM}_{1} \mathrm{SO}_{4}$ in the greater area of the archipelago. The average profile of airborne sulfate is rather homogeneous up to $2.2 \mathrm{~km}$ a.s.l. and shows average modelled (measured) concentration of $5.8(5.5) \mu^{-3} \mathrm{~g} \mathrm{~m}^{-3}$. Concentrations smoothly decline aloft, reaching lower values $\left(<1 \mu \mathrm{g} \mathrm{m}^{-3}\right)$ above $4.2 \mathrm{~km}$. The high uniformity and content in the vertical is a first indication that the low troposphere above the AS is a receptor of distant industrial plumes and medium-range sources, especially under strong NE winds (Fig. S1a). This also explains the higher sulfate concentration values in the lower troposphere above the AS (modelled: $5 \mu \mathrm{g} \mathrm{m}^{-3}$ and measured: $4.7 \mu \mathrm{g} \mathrm{m}^{-3}$ ) than above Turkey (which are 3.6 and $3.7 \mu \mathrm{g} \mathrm{m}^{-3}$, respectively).

The average model performance statistics have satisfactory values with $77 \%$ of the data pairs being within the $2: 1$ and $1: 2$ lines (Table S3). The MFB and MFE, when compared with the goals, rate the sulfate model system performance as good, with only $15 \%$ of the MFE values calculated for each data pair being outside the criteria lines.

The good model performance is also supported by checking each ground data pairs. Figure 3 shows all predictions of $\mathrm{PM}_{1} \mathrm{SO}_{4}$ against the respective available (PILS-IC) measurements from ground level, while Table S4 embeds the average ground statistics. The average modelled (measured) concentration is $5.9(6.4) \mu \mathrm{g} \mathrm{m}^{-3}$, representative of the aforementioned domain-wide average within the PBL over the archipelago. Most of MFE values meet the criteria with few outliers observed (14\% of the cases). Evidently, there is no clear diurnal cycle of sulfate during the studied period (Fig. 3). This is attributed to the lack of strong local sulfur dioxide $\left(\mathrm{SO}_{2}\right)$ sources (Pikridas et al., 2010), as well as to the continuous dispersion of the overflying plumes, during their transport over the sea.

Sulfate is the dominant species of the atmospheric aerosols, as indicated both by observations and predictions. This is in line with the majority of earlier long term observations and campaigns in the region (Sciare et al., 2008; Pikridas et al., 2010; Im et al., 2012). $\mathrm{PM}_{1} \mathrm{SO}_{4}$ production is related to its gaseous precursors $\left(\mathrm{SO}_{2}\right)$, mostly emitted from the industrialized areas in the Balkans, Turkey and eastern Europe (Sciare et al., 2003a, b; Pikridas et al., 2010), which is converted to sulfuric acid $\left(\mathrm{H}_{2} \mathrm{SO}_{4}\right)$ that has low vapour pressure and nucleates or condenses mainly in the aerosol fine mode (Mihalopoulos et al., 2007). The satisfactory comparison between model predictions and spatially divergent observations of sulfate over the greater area of the AS proves the representation of its sources and processes in the applied model system to be good.

\subsubsection{Exogenous influences}

Confidence in this model system allows the provision of supplementary information on the role of sulfur transport from outside the PMCAMx domain, not provided by the measurements. The origin of sulfate from the hot spot regions upwind of the archipelago is tracked by the calculation of the transported mass to the total $\mathrm{PM}_{1} \mathrm{SO}_{4}$ predictions (standard run - scenario 1, light red shaded area in Fig. 3). It is found that a notable part of area-wide episodic events is attributed by about $85 \%$ to trans-boundary transport of sulfate particles and its gaseous precursor during most of the studied period. The spatial distribution of daily mean sulfate concentrations over the domain of interest together with the contribution of the trans-boundary transport (standard run - scenario 1, isolines) is given for a representative Etesian day (Fig. 4a). The exact origin of $\mathrm{SO}_{4}$, determined by back-trajectory calculations (Bezantakos et al., 2013), is the eastern Europe and the wider Black Sea region. The remaining 10-15\% $\mathrm{SO}_{4}$ of $\mathrm{PM}_{1}$ is equally formed by sulfur emissions in the western continental part of Greece and sources in the Turkish area of the domain (scenario 2 - scenario 1 ).

A different pattern is observed on 31 August 2011, when the observed winds at Finokalia change to NW (Fig. S1a). The concentration map of this episode indicates that the air parcels passing over continental Greece (Athens and Peloponnese) head towards the south AS (Fig. 4b). During that day, trans-boundary pollution in the area is less important compared to the rest of the studied period. In particular, the submicron sulfate over the south AS (Finokalia) is equally shaped by the local (domain-wide) and by the exogenous sources, with $80 \%$ of the former originating from the Greek territory (scenario 2 - scenario 1). Interestingly, the peak values $\left(\sim 10 \mu \mathrm{g} \mathrm{m}^{-3}\right)$ at Finokalia observed during the sulfur transport from Greek power plants towards the south AS (Fig. 3) are lower than those related to the transport from the Balkans and from further NE $\left(\sim 12 \mu \mathrm{g} \mathrm{m}^{-3}\right)$. Model inconsistencies during this plume transport (Fig. 3) are related to the strong gradient from near-source to background, which is not accurately resolved and captured by the model's grid resolution. The exogenous influence on $\mathrm{SO}_{4}$ concentrations in the north Aegean remains high (70\%) on 31 August and originates from the continental area between the Black and the Caspian Sea (Bezantakos et al., 2013).

\subsubsection{Sensitivity of model performance}

The high spatial and temporal resolution of airborne measurements, allows for an extended diagnostic evaluation and may help to better address poor model system performance over the EM. Increased model discrepancies are mostly attributable to the lower and the higher ends of airborne $\mathrm{PM}_{1} \mathrm{SO}_{4}$ concentrations distribution (minimum and maximum observed values shown in Fig. 2a). Poor model performance for lower aerosol concentrations is explained be- 


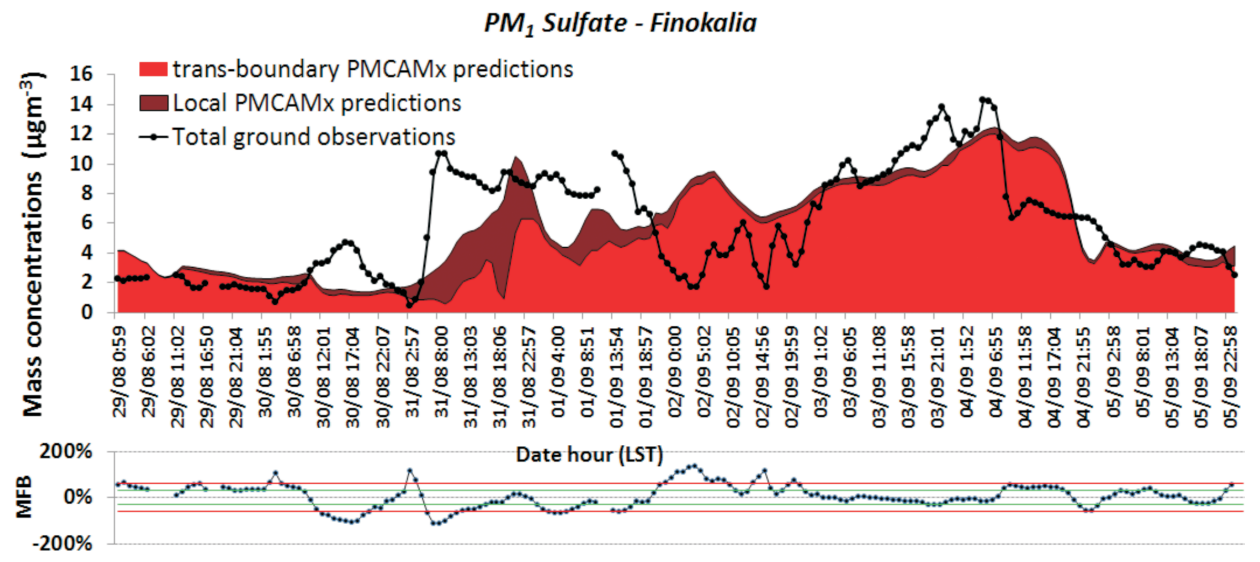

Figure 3. Comparison of PMCAMx (total shaded area) with hourly measurements (black dotted line) of total $\mathrm{PM}_{1}$ sulfate concentrations $\left(\mu \mathrm{g} \mathrm{m}^{-3}\right.$ ) over Finokalia during 31 August-09 September 2011. The contribution of PMCAMx predicted trans-boundary (standard run scenario 1 , in light red) and local (scenario 1, in dark red) to the total $\mathrm{PM}_{1}$ sulfate mass is also shown. The ability of the model to reproduce observations is estimated through the calculation of the mean fractional biases (MFB), shown at the bottom. Model performance is average (good), when MFB values are within the red (green) lines (Boylan and Russell, 2006).

low, although it is typical for aerosol concentrations below $2 \mu \mathrm{g} \mathrm{m}^{-3}$ (Boylan and Russell, 2006). The largest model underestimations occur mainly in the area of Chania, where measurements frequently exceed $14 \mu \mathrm{g} \mathrm{m}^{-3}$. Measurements during take-offs and landings are contaminated by local airport emissions, while predictions cannot ideally reproduce concentrated plumes, but are representative of a much wider area $\left(\sim 38 \mathrm{~km}^{2}\right)$ and time scales $(1 \mathrm{~h})$. Indeed, sulfate model predictions in the greater area of Chania $\left(6\right.$ to $\left.10 \mu \mathrm{g} \mathrm{m}^{-3}\right)$ are much closer to previous measurements ( 7 to $9 \mu \mathrm{g} \mathrm{m}^{-3}$ ) in a nearby, suburban area (Kopanakis et al., 2012). The maximum sulfate aerosol concentration $\left(23.4 \mu \mathrm{g} \mathrm{m}^{-3}\right)$ is observed in the lower troposphere $(\sim 1.7 \mathrm{~km})$ over Athens (02 September 2011, around 10:00 UTC). Here, the model under-prediction $\left(4.6 \mu \mathrm{g} \mathrm{m}^{-3}\right)$ is intensified by the narrow shape of the Athens pollution plume (relative to the size of the model grid size), as well as by the spatial and temporal changes in actual conditions and fuels used for transportation in the greater Athens area, that are not captured in emission inventories.

For more in-depth examinations regarding model system skills for sulfate predictions, MFE for airborne data are broken down for those parameters significantly affecting model performance (Table 4). As shown in this table, sulfate model performance is not consistent throughout the troposphere: it meets the goals at altitudes lower than $2.2 \mathrm{~km}$ a.s.l., but is poor at higher altitudes. This is more pronounced over Turkey ( $25 \%$ of the total number of data pairs over 27 to $29^{\circ} \mathrm{E}$, correspond to altitudes from 4 to $7 \mathrm{~km}$ a.s.l.) and it is because a few large deviations between low concentration values (below $1 \mu \mathrm{g} \mathrm{m}^{-3}$ ) can have a significant impact on the overall performance assessment.

The other two parameters affecting sulfate model skills are related to the wind conditions. Good model performance is observed under strong $\left(>9 \mathrm{~m} \mathrm{~s}^{-1}\right) \mathrm{NE}$ winds above the archipelago (local measurements along the flight tracks), that are typical of an Etesian pattern (Tombrou et al., 2015). Under NW and/or winds of lower intensity, sulfate predictions are still acceptable. The sensitivity of sulfate on the simulated wind is further examined by scenarios 5 (BOULAC PBL scheme) and 6 (QNSE PBL scheme), providing the lowest and strongest wind speeds respectively, below $2.2 \mathrm{~km}$ altitude. The average value inside the PBL layer ranges between 5.3 and $5.8 \mu \mathrm{g} \mathrm{m}^{-3}$, for an average wind speed variation from 8.6 (BOULAC) to 9.8 (QNSE) $\mathrm{m} \mathrm{s}^{-1}$ (below $2.2 \mathrm{~km}$ altitude) among the runs. Changes among concentration fields are anti-correlated with the wind fields, due to the higher dispersion of pollution that is associated with stronger winds. The aerosol model skills are rather insensitive to these variations, although scenario 6 exhibited the lowest MFB and MFE values (12.9 and $56.3 \%$, respectively) and the highest correlation with measurements $\left(r^{2}=0.4\right)$. Lastly, sulfate predictions showed a similar performance for all days (flights), independently of the time of day and latitude.

\subsection{Organic aerosols $\left(\mathrm{PM}_{1} \mathrm{OA}\right.$ and $\left.\mathrm{PM}_{10} \mathrm{OC}\right)$}

\subsubsection{Model evaluation}

Experimentally determined concentrations of the organic fraction of the submicron particles over the AS (Fig. 2b) are much lower than sulfate. In particular, the average measured concentration below $2.2 \mathrm{~km}$ a.s.l. is $4.2 \mu \mathrm{g} \mathrm{m}^{-3}$, with peaks ranging from 7 to $11 \mu \mathrm{g} \mathrm{m}^{-3}$. Similar findings have previously been observed in the AMS measurements at Finokalia (Hildebrandt et al., 2010; Pikridas et al., 2010).

Measurements of organic compounds over the archipelago below $2.2 \mathrm{~km}$ altitude are moderately underestimated by this model system (average predicted $\mathrm{PM}_{1} \mathrm{OA}$ value is 

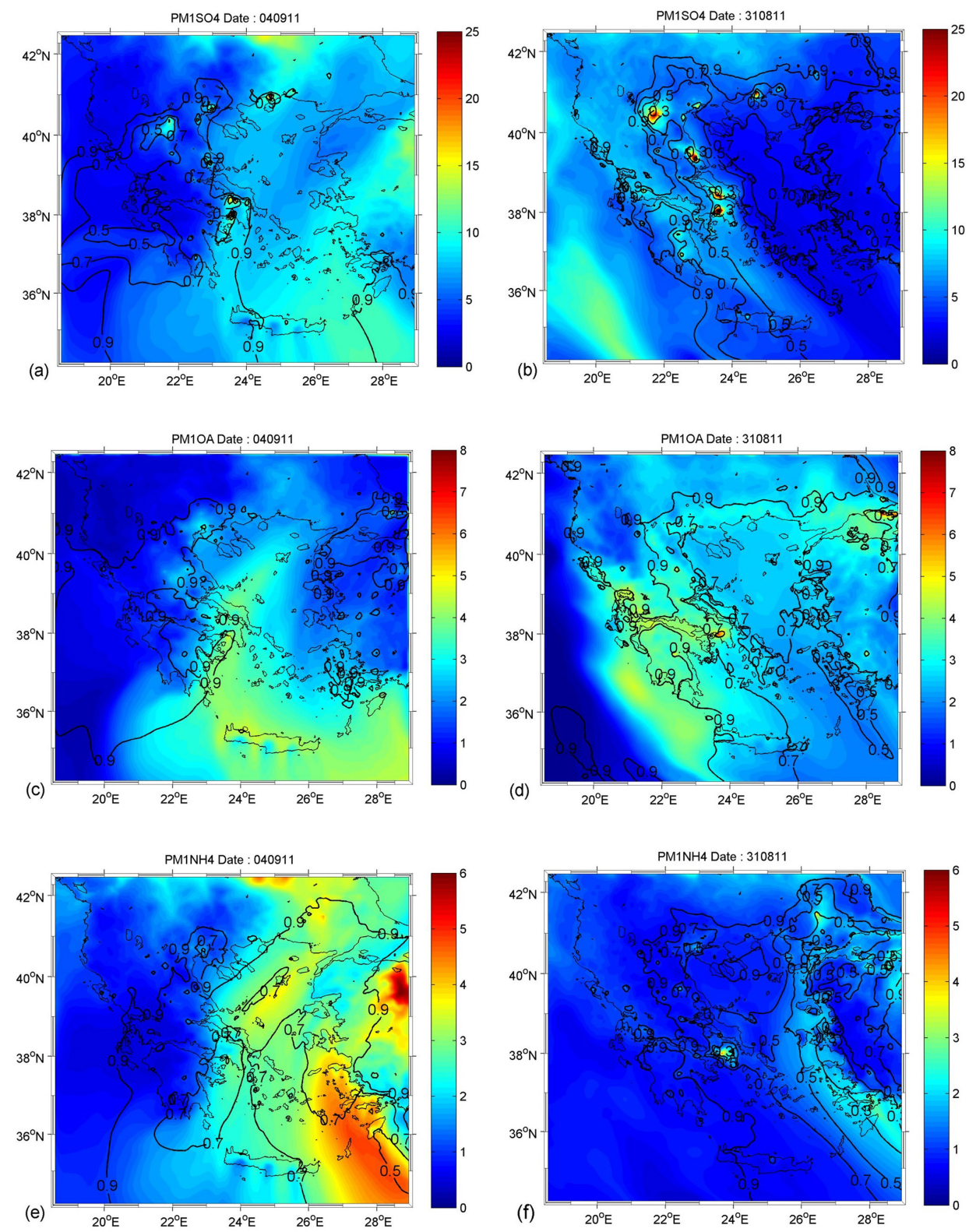

Figure 4. Daily average $\mathrm{PM}_{1}$ lowest level concentration fields $\left(\mu \mathrm{g} \mathrm{m}^{-3}\right.$ ) of sulfate, organics and ammonium species, during: (a), (c), (e) NE winds (04 September 2011) and (b), (d), (f) NW winds (31 August 2011), blowing over the Aegean Sea. Iso-lines show the contribution of trans-boundary sources to the total aerosol mass [(standard run - scenario 1)/standard run].

$2.3 \mu \mathrm{g} \mathrm{m}^{-3}$ ), which is consistent with findings reported by many modelling studies (e.g. Zhang et al., 2014, and references therein). Also, the comparison of GEOS-CHEM results with integrated global airborne observations resulted in the underestimation of the median OA concentrations in 13 of the 17 aircraft campaigns over central Europe, North America and western Africa (Heald et al., 2011). The main reasons for such underestimations were the poor model representation of SOA, as well as the lack of important sources and sinks of OA. The sources of error that may have con- tributed to the unaccounted OA mass in the current model system are investigated in Sects. 4.3.3, 4.3.4 and 4.3.6.

The calculated organic aerosol model skills in the PBL show an acceptable performance, with $58 \%$ of the model predictions meeting the performance criteria (Table S3). Also, PBL model predictions are better correlated to the observed aerosol distribution for organics $\left(r^{2}=0.6\right)$ than for sulfate $\left(r^{2}=0.3\right)$. This can be explained by the fact that the injection heights of the sulfuric compounds emitted from the industry range from 0 to $1 \mathrm{~km}$ a.g.l. (e.g. Mailler et al., 2013), 
Table 4. Mean and mean fractional error (MFE) values for the complete sample and for paired sub-samples of the airborne modelmeasurement data set. Paired sampling is based on the methodology described in Sect. 3.4. MFE with bold italic (italic) fonts indicate good (poor) model performance, according to the selected evaluation criteria (cf. Table S2). The rest of the model outputs (MFE with black fonts) are acceptable (average model performance).

\begin{tabular}{|c|c|c|c|c|c|c|}
\hline Airborne $\mathrm{PM}_{1}$ & \multicolumn{2}{|c|}{ Sulfate $\left(\mu \mathrm{g} \mathrm{m}^{-3}\right)$} & \multicolumn{2}{|c|}{ Ammonium $\left(\mu \mathrm{g} \mathrm{m}^{-3}\right)$} & \multicolumn{2}{|c|}{ Organics $\left(\mu \mathrm{g} \mathrm{m}^{-3}\right)$} \\
\hline $\begin{array}{l}\text { PMCAMx mean (min-max) } \\
\text { AMS mean (min-max) } \\
\text { MFE ( } \% \text { meets goals/criteria) }\end{array}$ & \multicolumn{2}{|c|}{$\begin{array}{c}4.8(0.3-12.1) \\
5(0.2-23.4) \\
55(56 / 73)\end{array}$} & \multicolumn{2}{|c|}{$\begin{array}{c}1.1(0.05-4.2) \\
1(0.05-5.2) \\
63(70 / 79)\end{array}$} & \multicolumn{2}{|c|}{$\begin{array}{c}1.4(0.01-6.8) \\
2.4(0.05-10.7) \\
83(51)\end{array}$} \\
\hline 1st pair of samples & $<2.2$ & $>2.2 \mathrm{~km}$ a.s.l. & & & $<2.2$ & $>2.2 \mathrm{~km}$ a.s. 1 \\
\hline $\begin{array}{l}\text { PMCAMx mean (min-max) } \\
\text { AMS mean (min-max) } \\
\text { MFE ( } \% \text { meets goals/criteria) }\end{array}$ & $\begin{array}{l}5.5(1.1-12.1) \\
5.8(0.2-23.4) \\
44(64 / 82)\end{array}$ & $\begin{array}{l}3.8(0.3-9.7) \\
3.7(0.2-15) \\
72(<50 / 59)\end{array}$ & & & $\begin{array}{l}2.3(0.2-6.8) \\
4.4(0.1-10.7) \\
\mathbf{7 4}(<50 / \mathbf{5 8})\end{array}$ & $\begin{array}{l}0.9(0.01-4.8) \\
1.1(0.05-9.4) \\
89(<50 / 50)\end{array}$ \\
\hline 2nd pair of samples & Aegean & Turkey & Aegean & Turkey & Aegean & Turkey \\
\hline $\begin{array}{l}\text { PMCAMx mean (min-max) } \\
\text { AMS mean (min-max) } \\
\text { MFE ( } \% \text { meets goals/criteria) }\end{array}$ & $\begin{array}{l}5(0.5-12.1) \\
4.7(0.2-20.4) \\
48(63 / 79)\end{array}$ & $\begin{array}{l}3.3(0.3-10.7) \\
3.5(0.2-19.6) \\
85(<40 / 46)\end{array}$ & $\begin{array}{l}1.3(0.06-4.2) \\
1.1(0.05-4) \\
54(79 / 87)\end{array}$ & $\begin{array}{l}0.8(0.05-2.7) \\
0.4(0.05-2) \\
71(62 / 76)\end{array}$ & $\begin{array}{l}2(0.1-5.6) \\
3.4(0.05-9.3) \\
77(<60 / 60)\end{array}$ & $\begin{array}{l}0.5(0.01-4.8) \\
0.7(0.05-8) \\
92(<30 / 36)\end{array}$ \\
\hline 3rd pair of samples & NE & NW winds & & & NE & NW winds \\
\hline $\begin{array}{l}\text { PMCAMx mean (min-max) } \\
\text { AMS mean (min-max) } \\
\text { MFE ( } \% \text { meets goals/criteria) }\end{array}$ & $\begin{array}{l}5.4(0.7-11.5) \\
5.6(0.2-23.4) \\
\mathbf{5 1}(\mathbf{6 0} / 77)\end{array}$ & $\begin{array}{l}4(0.3 / 12.1) \\
4.1(0.2-20.4) \\
61(<60 / 69)\end{array}$ & & & $\begin{array}{l}1.9(0.02-5.6) \\
3.2(0.05-10.4) \\
\mathbf{7 6}(<60 / \mathbf{6 2})\end{array}$ & $\begin{array}{l}1(0.01-6.8) \\
1.6(0.05-10.7) \\
89(<40 / 42)\end{array}$ \\
\hline 4th pair of samples & $U>9$ & $<9 \mathrm{~ms} \mathrm{~s}^{-1}$ & $U>9$ & $<9 \mathrm{~ms} \mathrm{~s}^{-1}$ & & \\
\hline $\begin{array}{l}\text { PMCAMx mean (min-max) } \\
\text { AMS mean (min-max) } \\
\text { MFE ( } \% \text { meets goals/criteria) }\end{array}$ & $\begin{array}{l}5.1(0.4-12.1) \\
5.5(0.2-23.4) \\
46(\mathbf{6 2 / 8 2})\end{array}$ & $\begin{array}{l}4.5(0.3-11.3) \\
4.5(0.2-20.42) \\
63(<60 / 65)\end{array}$ & $\begin{array}{l}1.5(0.06-4.2) \\
1.2(0.05-4.3) \\
52(80 / 100)\end{array}$ & $\begin{array}{l}0.8(0.05-3.1) \\
0.9(0.05-5.2) \\
71(61 / 72)\end{array}$ & & \\
\hline
\end{tabular}

whereas the large oxygenated fraction of organics in the AS troposphere creates a more homogeneous field.

Modelled organic concentrations $\left(\mathrm{PM}_{10} \mathrm{OA}\right)$ are divided here by a factor of 2.1, to extract the organic carbon mass concentrations over non-urban areas (see explanation in Sect. 3.2), which can be compared to ground $\mathrm{PM}_{10}$ OC measurements. Model performance is good (Fig. 5 and Table S4), with $41(82) \%$ of the model predictions meeting the performance goals (criteria). The average $\mathrm{PM}_{10}$ OC concentration values are similar over the north and south AS (2.3 and $2.9 \mathrm{\mu g} \mathrm{m}^{-3}$, respectively), indicating the absence of major local OA sources, which can also explain the smaller range of their spatial variability.

\subsubsection{OA analysis}

The experimental data obtained during this study cannot separate SOA from OA, their biogenic from their anthropogenic part, as well as the fine from the coarse organic $\mathrm{PM}_{10}$ fraction. Model outputs are used to help untangle these contributions (cf. Fig. 5). Similar predictions over both measurement sites suggest again the large spatial homogeneity of organic particles over the archipelago. Up to $40 \%$ of $\mathrm{PM}_{10}$ organics are located between 1 and $10 \mu \mathrm{m}$ (which is slightly higher compared to the $25 \%$ experimentally determined at Finokalia by Sciare et al., 2003a), $75 \%$ of which is coarse
$\left(\mathrm{PM}_{2.5-10}\right)$. Submicron OA over the AS are mainly secondary (95\%) and originate primarily ( $80 \%)$ from biogenic sources, which is explained in the next paragraph. Most of these results are consistent with previous studies covering the region of the AS (Hildebrandt et al., 2010; Athanasopoulou et al., 2013), and are explained by the aged nature of the OA over the sea, especially during the summer period.

\subsubsection{Uncertainties in OA treatment}

Previous PMCAMx applications over Europe using the VBS scheme for SOA formation (Fountoukis et al., 2011, 2014), have been shown to be competent in predicting realistic levels of $\mathrm{PM}_{1} \mathrm{OA}$ over the south Aegean Archipelago (Finokalia). Those applications neglected the chemical ageing of BSOA assuming that it is not expected to significantly contribute to the OA concentration levels. Interestingly, our results indicate that the activation chemical ageing of BSOA (standard run) leads to a significant improvement of the OA levels over the Aegean Sea (cf. continuous green line in Fig. 2b). In particular, the BSOA oxidation in the troposphere over the AS increases the total OA mass predictions by 50 to $80 \%$ during the whole simulation period. The reason that BSOA are likely to undergo atmospheric ageing lies in the sufficient quantities of anthropogenic nitrogen and sulfur pollutants in the atmosphere over the AS $\left(\mathrm{NO}_{x}=1\right.$ to $2 \mathrm{ppb}$, 


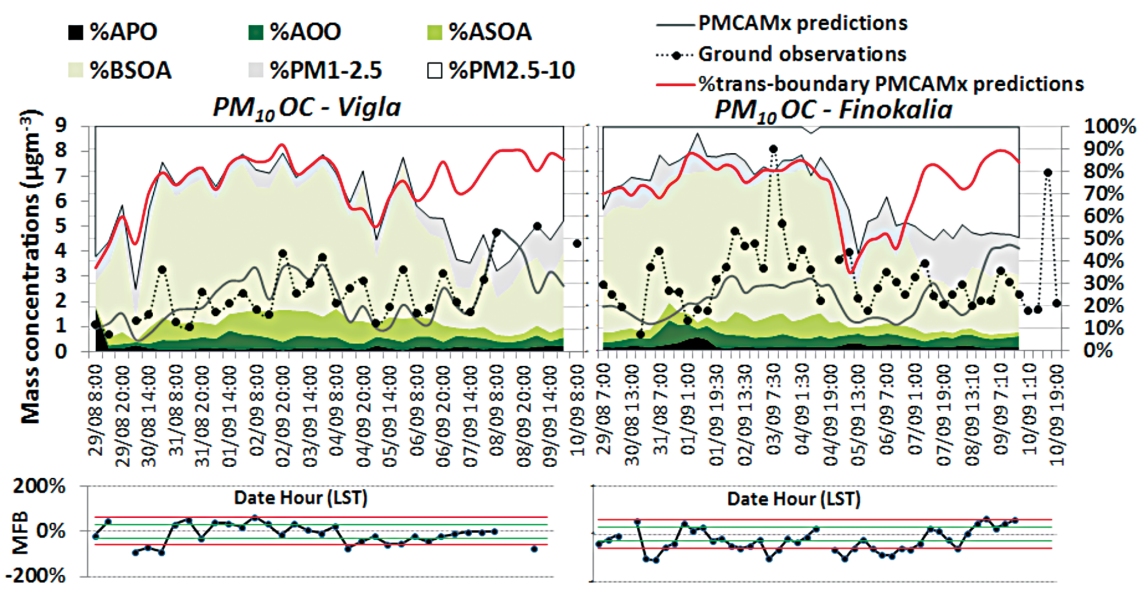

Figure 5. Comparison of PMCAMx (grey lines) with 6-h measurements (black dotted line) of total $\mathrm{PM}_{10} \mathrm{OC}_{\text {concentrations }}\left(\mu \mathrm{g} \mathrm{m}^{-3}\right.$ ) over Vigla (left) and Finokalia (right) during 31 August-09 September 2011. The relative contribution of PMCAMx predicted trans-boundary (standard run - scenario 1, red line) to the total $\mathrm{PM}_{10}$ OA mass is also shown. Green shaded areas represent the chemical composition of $\mathrm{PM}_{1}$ OA predictions, grey shaded area shows the organics in the $\mathrm{PM}_{1-2.5}$ size range, while the remaining (white shaded area) represents the organics in the coarse fraction $\left(\mathrm{PM}_{2.5-10}\right)$. All areas are percentage values. The ability of the model to reproduce observations is estimated through the calculation of the mean fractional biases (MFB), shown at the bottom. Model performance is average (good), when MFB values are within the red (green) lines (Boylan and Russell, 2006). The predicted OC is acquired by dividing OA by 2.1 (Turpin and Lim, 2001 ).

mean molar ratio $\mathrm{NH}_{4}^{+} / \mathrm{SO}_{4}^{2-} \leq 2$ ), which facilitates BSOA oxidation (cf. Zhao et al., 2013, and references therein). As a consequence, deactivating BSOA ageing (scenario 3; dotted green line in Fig. 2b) changed the model skills for organics from average to poor (average predicted value from scenario 3 is $0.7 \mu \mathrm{g} \mathrm{m}^{-3}$ for the atmosphere up to $2.2 \mathrm{~km}$ a.s.l. over the AS).

The sensitivity of the model results on ASOA ageing (standard run - scenario 4) was limited to $5 \%$ both for the average $\mathrm{OA}$ concentration predictions and their chemical composition. In particular, the faster oxidation rate of anthropogenic SOA resulted in a minor increase (up to $10 \%$ ) of the predicted OA during the whole simulation period of scenario 4 . Such a different model response to BSOA/ASOA changes stems from the isoprene / aromatics concentration ratio from GEOS-CHEM (ICs), which takes the average value of 9/1 over the AS. Scenario 4 had a positive though minor effect on performance metrics.

A possible error in OA predictions introduced by the VBS mechanism is that species with similar volatilities can have different properties and reactivities. Nevertheless, the development of more complex VBS schemes with respect to these issues (Donahue et al., 2011) has already shown no significant improvements in OA performance over Europe. This is probably due to uncertainties in our understanding of SOA evolution in the atmosphere (Murphy et al., 2012).

In case the VBS chemical module would have introduced significant errors, then OA estimations would have performed similarly throughout the troposphere. In contrast, the OC model performance at both ground locations has been rated as "good" (cf. Sect. 4.3.1), while the calculated statis- tics for the paired sampling for airborne organics revealed an inconsistent behaviour of biases throughout the troposphere (Table 4). The model performance in the upper atmosphere and especially in the area above Turkey (elevated flight paths, low concentration values, as described in the previous section) is rated as "poor" and deteriorates the overall organic model performance.

Overall, the well-established VBS scheme is investigated and revisited, so that it better describes OA behaviour over the southeastern Mediterranean during summertime. The current SOA treatment is found to be satisfactory and it is not regarded as introducing important errors in OA predictions.

\subsubsection{Biomass burning component}

Biomass burning (BB) plumes may enter the free troposphere and be advected over very long distances, especially under strong winds. Back trajectory calculations from 400 to $4500 \mathrm{~m}$ a.s.l. (Bezantakos et al., 2013) show that the air masses arriving over the archipelago during the studied period, mostly originate from (or pass over) the eastern Balkan area and the west coastline of the Black Sea, where there is evidence (satellite observations) of fire activity during (and prior to) the study period (Fig. S2). Consistent with these observations, the comparison between the current model outputs and measurements of OA when NE winds prevail shows an average difference of $1.3 \mu \mathrm{g} \mathrm{m}^{-3}$ (Table 4). When the prevailing winds have a NW direction (the air masses arriving over the AS basin do not seem to originate/pass from fire spots, according to the same back-trajectory analysis), the difference between OA values from the model and observations is lower $\left(0.6 \mu \mathrm{g} \mathrm{m}^{-3}\right.$; cf. Table 4$)$. 
Based on this evidence, bb particles are found to be an important component of $\mathrm{PM}_{1} \mathrm{OA}$ over the AS during summer, which can largely explain the $\mathrm{PM}_{1}$ OA underestimation (ca. $50 \%$ ) by the current model application, which lacks representation of fire emissions (cf. Sect. S2). This is a quite realistic hypothesis, given the observations reported by Sciare et al. (2008) and Bougiatioti et al. (2014). In particular, the systematic measurements of aerosols in the southern AS region (Finokalia) during late summer have shown that 30-35\% of OA comes from biomass burning in the eastern Balkans and at the European countries surrounding the Black Sea. Bossioli et al. (2014) have shown that the wildfire emissions sector contributes on average ca. $50-60 \%$ to the total $\mathrm{PM}_{1} \mathrm{OA}$ mass predictions in the AS region during the summer, which further supports our speculation.

\subsubsection{Other exogenous influences}

Organic aerosol mass and gaseous (VOC) precursors from the Balkans and further north, shapes more than $90 \%$ of their total concentration levels over the AS during the Etesian event (Fig. 4c). The effect of organic-rich plumes from continental Greece during the non-Etesian event (with prevailing NW winds, Fig. 4d), as well as the domain-wide photochemistry, decrease slightly the role of exogenous sources (now $70 \%$ on average) over the whole region of the AS. Examining the different chemical constituents of the transported SOA and precursors ( 34 to 41 gaseous and 4 to 11 aerosol paired species as listed in Table 2) in the studied domain, shows that the exogenous organic mass primarily originates from isoprene (mean NE boundary concentration values of 1 to $2 \mu \mathrm{g} \mathrm{m}^{-3}$ ), while aromatics are 2 to 6 times lower. The rest of the transported organic species (a-pinene, myrcene, sesquiterpenes etc) are insignificant. It should be noted that these findings correspond to the accounted sources of OA particles (and their precursors) by the current model setup, which do not reflect $\mathrm{BB}$, as discussed in the previous section.

\subsubsection{Other model performance issues}

In order to further investigate the underestimation of the model to other important sources of OA, we performed a series of sensitivity tests. Independent artificial increases in emissions from the road transport, maritime and industrial sectors showed insignificant changes in the organic aerosol predictions. An additional scenario (increased values) for the applied BCs from GEOS-CHEM resulted in unrealistically high $\mathrm{OA}$ concentration outputs. In general, although some uncertainty in the emission inventory as well as in GEOS-CHEM performance cannot be excluded, these do not contribute substantially to the OA underestimation, pointing again to the fire activity to be the main deficiency in the current model application with respect to OA results.

Wind also affects the quality of organic aerosol predictions, but only regarding direction, as already explained in
Sect. 4.3.4 The day, time of day, latitude and wind speed do not affect organic aerosol model performance. The latter is also confirmed by scenarios 5 and 6 (MFE $=72$ to $80 \%$ ), although scenario 5 , which was based on slightly lower winds (i.e. lower dispersion), produced slightly higher concentration values having the subsequent (though minor) reduced model bias.

\subsection{Ammonium aerosols $\left(\mathrm{PM}_{1} \mathrm{NH}_{4}\right)$}

The hourly variation of airborne ammonium concentration predictions is consistent with the observations (Fig. 2c). Apart from the expected inconsistencies in the observed peak values already discussed, performance issues are tied with sulfate inconsistencies (e.g. during 04 September 2011). This is related to the fact that during summer most of the ammonium is associated with the sulfate rather than the nitrate fraction.

The average predicted (observed) PBL concentration of $\mathrm{PM}_{1} \mathrm{NH}_{4}$ is 1.6 (1.4) $\mu \mathrm{g} \mathrm{m}^{-3}$, which is consistent with the ground ammonium concentrations in earlier measurements at Finokalia (Kouvarakis et al., 2001; Metzger et al., 2006; Pikridas et al., 2010). Regardless of the high uncertainties in ammonia emissions usually incorporated in the photochemical models (Skjøth et al., 2011), the reproduction of the observed data by the current model system is high, i.e. 70 (79) $\%$ of the MFE values meet the goals (criteria). The overall model performance for the ammonium species is good and optimized over the archipelago and under strong winds (Table 4). The rest of the examined parameters (flight/day, time of day, altitude, latitude and wind direction) do not seem to affect model performance with respect to ammonium.

Air parcels arriving in the simulation domain are predicted to contribute ca. $70 \%$ of the average $\mathrm{PM}_{1} \mathrm{NH}_{4}$ concentrations when originating from a NE direction (Fig. 4e) and by a lower percentage (though above $50 \%$ ) when originating from NW (Fig. 4f).

\subsection{Nitrate and chloride aerosols $\left(\mathrm{PM}_{1} \mathrm{NO}_{3}\right.$ and $\left.\mathrm{Cl}\right)$}

The measured non-refractory submicron nitrate concentrations below $2.2 \mathrm{~km}$ a.s.l. $\left(0.2 \mu \mathrm{g} \mathrm{m}^{-3}\right.$ in average $)$ are strongly overestimated by the model system $\left(1.9 \mu \mathrm{g} \mathrm{m}^{-3}\right)$ (as shown in Table S3). This is attributed to two distinct reasons: the sea-salt component of nitrate (standard run - scenario 7), which is not captured by the AMS measurements, accounts for the $54 \%$ of $\mathrm{PM}_{1} \mathrm{NO}_{3}^{-}$predictions. Also, the average exogenous contribution from upwind (standard run - scenario 1) is ca. $1 \mu \mathrm{g} \mathrm{m}^{-3}$, which is unrealistic according to current measurements. When subtracting these mass fractions from total $\mathrm{PM}_{1} \mathrm{NO}_{3}$ predictions, the model results become more realistic. Nevertheless, it should be kept in mind that performance issues are commonly tied to low concentration $\left(<1 \mu \mathrm{g} \mathrm{m}^{-3}\right)$ cases, not only because they greatly degrade 

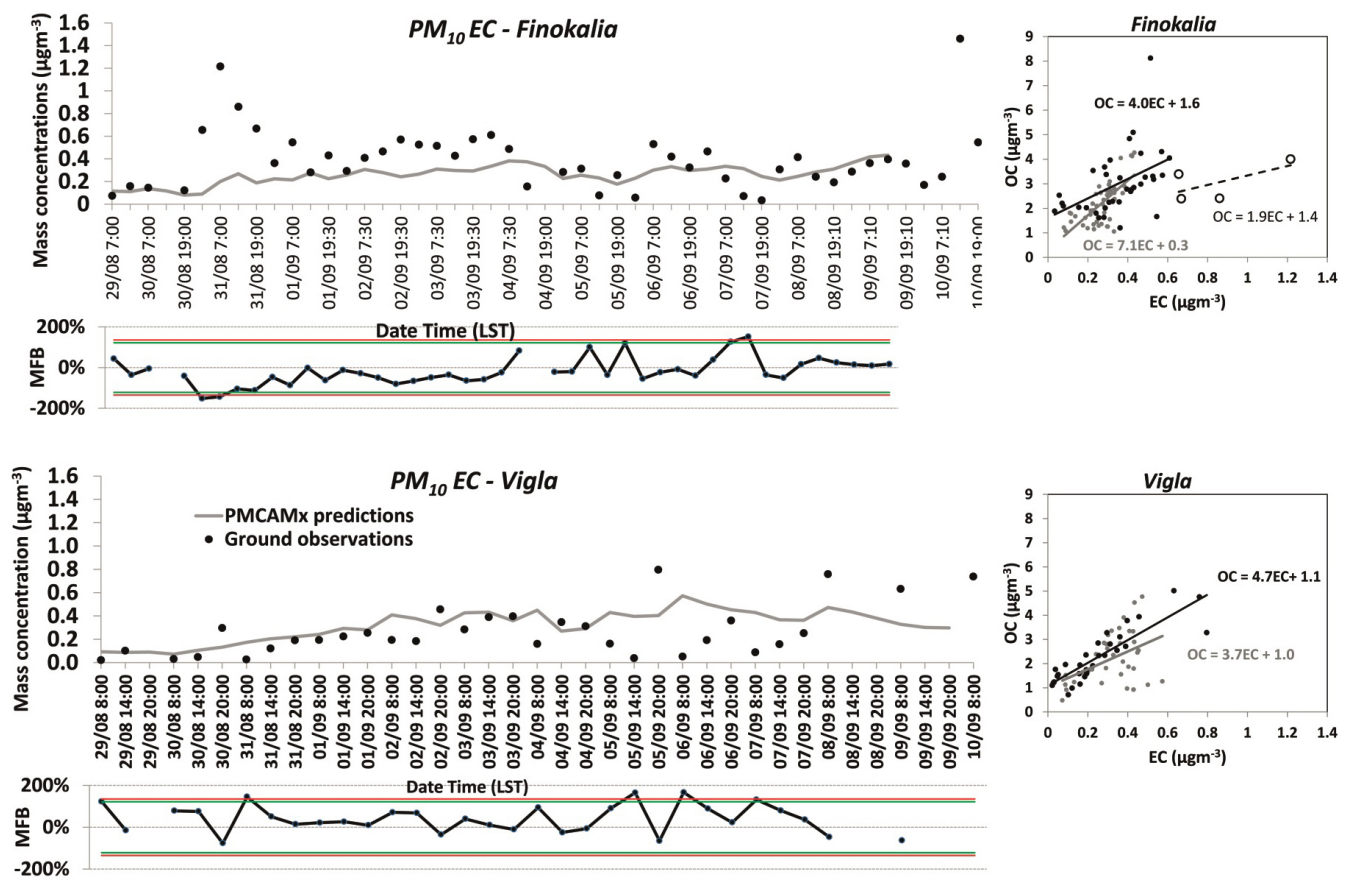

Figure 6. Comparison of PMCAMx (grey lines) with 6-h measurements (black dots) of $\mathrm{PM}_{10}$ elemental carbon concentrations $\left(\mu \mathrm{g} \mathrm{m}^{-3}\right.$ ) over Vigla (top) and Finokalia (bottom) during 31 August-09 September 2011. The ability of the model to reproduce observations is estimated through the calculation of the mean fractional biases (MFB), shown at the bottom of each graph. Model performance is average (good), when MFB values are within the red (green) lines (Boylan and Russell, 2006). OC versus EC (grey/PMCAMx and black/measurements data points and lines) in $\mathrm{PM}_{10}$ is shown on the right of each graph. The black dashed line in Finokalia reflects the slope of OC to EC for the measurements during the NW transport from continental Greek sources (black empty circles, 31 August 2011).

normalized model performance, but also due to the higher uncertainty of measurements.

Measured (submicron non-refractory) and modelled chloride is low $\left(<0.8 \mu \mathrm{g} \mathrm{m}^{-3}\right)$, because of the insignificant seasalt content in the submicron fraction, the inability of AMS to measure sea-salt chloride, as well as its gradual displacement by nitrate and sulfate ions. Nevertheless, model performance is found to be good (Table S3).

\subsection{Particulate elemental carbon (PM $\mathbf{P M}_{10}$ EC)}

Figure 6 shows the diurnal variation of the $\mathrm{PM}_{10} \mathrm{EC}$ for the ground sites of the south and north Aegean basin. Both the absolute values and their temporal evolution are well reproduced by the model. In particular, the average measured (and modelled) concentration is ca. $0.3 \mu \mathrm{g} \mathrm{m}^{-3}$, and therefore the model performance is rated as good (Table S4), with a few exceptional outliers. Elemental carbon is dominated by combustion sources. Thus, it can be assumed that the fossil fuel sources are well represented by the emission data sets used by this model system.

As for sulfate, the footprint of continental Greek sources (mainly from the Athens metropolitan area) is apparent in EC concentrations at Finokalia during the prevailing NW directions $\left(0.6\right.$ to $\left.1.2 \mu \mathrm{g} \mathrm{m}^{-3}\right)$. During the rest of the period, EC levels fluctuate at similar levels at both sites.
Unlike $\mathrm{PM}_{1}$ OA performance, no model underestimation related to the fire activity upwind is observed for surface $\mathrm{PM}_{10}$ EC. This is mainly because the long-range transport of fire plumes is more efficient in higher altitudes due to the lack of surface deposition and stronger winds. Likewise, the $\mathrm{PM}_{10}$ OC measurements near ground, although slightly underestimated by the model system (cf. Table S4), perform much better than $\mathrm{PM}_{1} \mathrm{OA}$ in and above the PBL (cf. Table 4). In parallel, the signal of fires on the low levels of ground EC (average values of observations and predictions are largely below $1 \mu \mathrm{g} \mathrm{m}^{-3}$ ), already reported by Sciare et al. (2008), is most probably within the biases (ca. the $40 \%$ of them is above $0.2 \mu \mathrm{g} \mathrm{m}^{-3}$ ) over the AS during summertime. The $\mathrm{OC} / \mathrm{EC}$ ratio from the measured (modelled) data during this period is as high as $4.7(4.0)$ and $4.0(7.1)$ at the north (Vigla) and south (Finokalia) AS (Fig. 6), being at similar levels with those measured previously in Finokalia (Koulouri et al., 2008; Pikridas et al., 2010; Im et al., 2012). OC / EC slopes greater than 2 suggest the significant fraction of secondary species in the organic aerosol mass in background areas, as predicted and previously discussed in Sect. 4.3. The lower OC / EC slope at Finokalia during 31 August (1.9) is close to previous findings in urban areas (Favez et al., 2008; Theodosi et al., 2010) and is related to the higher EC levels during 


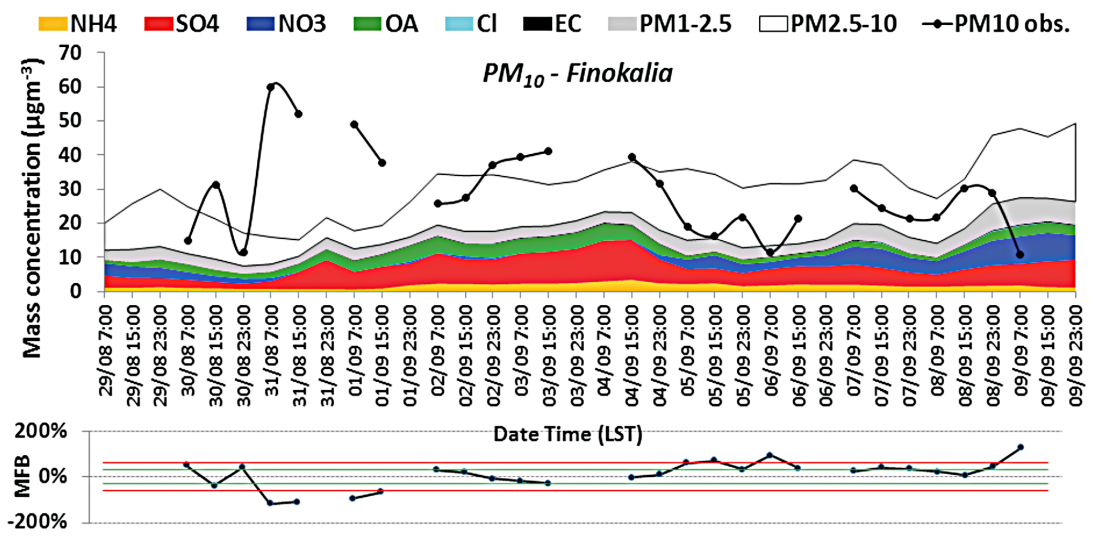

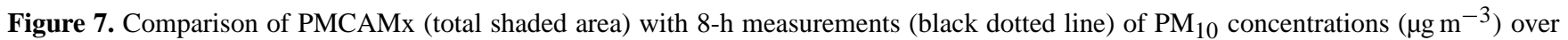
Finokalia during 31 August-09 September 2011. Colour shaded areas represent the chemical composition of $\mathrm{PM}_{1}$ predictions, the grey shaded area shows the $\mathrm{PM}_{1-2.5}$, while the remaining (white shaded area) represents the coarse fraction $\left(\mathrm{PM}_{2.5-10}\right)$. The ability of the model to reproduce observations is estimated through the calculation of the mean fractional biases (MFB), shown at the bottom. Model performance is average (good), when MFB values are within the red (green) lines (Boylan and Russell, 2006).

the urban plume transport from the NW. The latter was also depicted in the spatial distribution of sulfate (Fig. 4b).

\subsection{Particulate matter $\left(\mathbf{P M}_{10}\right)$}

The average predicted total $\mathrm{PM}_{10}$ mass at Finokalia during the simulated period is found to be $30.1 \mu \mathrm{g} \mathrm{m}^{-3}$. This value is very close to the average of the concurrent observations $\left(29 \mu \mathrm{g} \mathrm{m}^{-3}\right)$, as well as to previous measurements in non-urban areas of the Mediterranean region (Rodriguez et al., 2001; Gerasopoulos et al., 2006; Lazaridis et al., 2008; Koulouri et al., 2008; Kopanakis et al., 2012). The performance skills of the model system on $\mathrm{PM}_{10}$ predictions are rated as good (Table $\mathrm{S} 4$ ) and the daily evolution of $\mathrm{PM}_{10}$ predictions is satisfactory (Fig. 7). Atypically high $\mathrm{PM}_{10}$ concentration levels observed at Finokalia on 01 September suggest that the quality of sampling on this particular day might be questionable.

The combined use of measurement and modelling techniques during this period is useful for the estimation of the chemical composition and the size distribution of $\mathrm{PM}_{10}$ measurements at Finokalia (Fig. 7). Sulfate account for the $45 \%$ of $\mathrm{PM}_{1}$ mass, followed by OM. The latter represents the $20 \%$ of $\mathrm{PM}_{1}\left(2.6 \mu \mathrm{g} \mathrm{m}^{-3}\right)$, which is similar to measurements at Finokalia (Pikridas et al., 2010). The predicted submicron ammonium content at Finokalia $\left(1.7 \mu \mathrm{g} \mathrm{m}^{-3}\right)$ is consistent either with the current airborne or with the past ground-based observations at this site (Sect. 4.4). The contribution of the rest aerosol species $(\mathrm{Cl}$ and $\mathrm{EC})$ is minor (2\%). The levels of the submicron nitrate are greatly overestimated by the model system (Sect. 4.5).

Submicron aerosol is the largest fraction of the $\mathrm{PM}_{2.5}$ mass (76\%), but accounts for $42 \%$ of the total $\mathrm{PM}_{10}$. This is mostly related to the elevated coarse aerosol concentrations $\left(14.2 \mu \mathrm{g} \mathrm{m}^{-3}\right)$, which shape the $\mathrm{PM}_{2.5} / \mathrm{PM}_{10}$ ratio around
$54 \%$. Previous ground-based observations over the EM have resulted in fractions ca. $50 \%$ (Kanakidou et al., 2011), further supporting the satisfactory aerosol predictions over the whole size range by this model system.

Given the similar levels of ground and airborne measurements over the AS and below $2.2 \mathrm{~km}$ a.s.l. (discussed in Sects. 4.2-4.5), it can be stated that the current analysis of the ground $\mathrm{PM}_{10}$ measurements performed by the model is representative of the PBL above the archipelago during strong northern winds.

\section{Summary and conclusions}

A recently applied model system consisting of three wellestablished atmospheric models (namely, PMCAMx, WRF and GEOS-CHEM), and a unique aerosol data set collected in the EM are synergistically used in the frame of this study during a 10-day period characterized by strong northern winds (August-September 2011). The aircraft data set used represents a spatially diverse set of aerosol observations (covering the horizontal area of ca. $3 \times 10^{5} \mathrm{~km}^{2}$ and extending from the sea surface to $7.5 \mathrm{~km}$ aloft), employed to perform the most extensive - to our knowledge - model evaluation of major aerosol chemical component concentrations over the EM to date ( $>1300$ observation-prediction samples per species).

The vertical resolution in the measurements allowed the exploration of the aerosol profiles above the Aegean Sea. The PBL above the archipelago $(<2.2 \mathrm{~km}$ a.s.l.) is homogenously enriched in sulfate (average modelled and measured $\mathrm{PM}_{1} \mathrm{SO}_{4}$ of 5.5 and $5.8 \mu \mathrm{g} \mathrm{m}^{-3}$, respectively), followed by organics (2.3 and $\left.4.4 \mu \mathrm{g} \mathrm{m}^{-3}\right)$ and ammonium (1.5 and $\left.1.7 \mathrm{~g} \mathrm{~m}^{-3}\right)$. Aerosol concentrations smoothly decline aloft, reaching low values $\left(<1 \mu \mathrm{g} \mathrm{m}^{-3}\right)$ above $4.2 \mathrm{~km}$. 
Aerosol model performance within the PBL is largely within an acceptable level of accuracy (for all major chemical species except for nitrate), or even close to the best level of accuracy (sulfate, ammonium and chloride satisfy the criteria), with 50 to $80 \%$ reproduction of these standards. Comparison with the ground-based observations (356 observation-prediction samples in total) suggested an even higher model quality, with a good reproducibility of all studied species and a few outliers $(<15 \%$ outside the criteria lines).

Wide and commonly found under-predictions in sulfate, elemental carbon and coarse aerosols (cf. Nopmongcol et al., 2012) are not observed in the current study. Also, in contrast to the uncertainties in ammonia emissions usually reported in air quality modelling (e.g. Skjøth et al., 2011), the observed ammonium levels are well reproduced here. These findings support that the power plants, motorways and natural aerosol sources, including agricultural activities of the surrounding area of the archipelago and upwind, are well represented and treated by this model system.

Relatively high OC / EC ratios (4 to 5) from the ground observations are successively reproduced by the PMCAMx model (OC / EC: 4 to 7), suggesting the large oxygenation rate of the organic matter above the archipelago, nicely represented by the employed OA chemical module. The activation of the chemical ageing of BSOA in this formulation, greatly improves model performance due to the sufficient $\mathrm{NO}_{x}$ concentration and the sulfate-rich Aegean environment. On the other hand, OA predictions showed minor (or unrealistic) response to anthropogenic emissions and variations in BCs. The fire activity, not taken into account by the current model application, is the main cause of OA underestimation (ca. 50\%), which is consistent with local measurements of the fire-induced OA fraction (e.g. Bougiatioti et al., 2014). This finding serves as a challenge for future model development.

Model performance was also dependent on the altitude (below and above $2.2 \mathrm{~km}$ ), the longitude (western and eastern than $27^{\circ} \mathrm{E}$, i.e. above the AS and western Turkey, respectively), the wind speed (above and below $9 \mathrm{~m} \mathrm{~s}^{-1}$ ) and wind direction (NE and NW) over the studied area. The (time of) day and latitude did not affect model biases. The sensitivity of aerosol predictions on different PBL schemes showed a minor effect on aerosol concentrations (e.g. 5.3 to $5.8 \mu \mathrm{g} \mathrm{m}^{-3}$ and 2.1 to $2.4 \mu \mathrm{g} \mathrm{m}^{-3}$ for airborne sulfate and organics, respectively), and did not change model performance. Overall, aerosol predictions within the PBL over the archipelago under strong NE winds showed the best performance.

More than $70 \%$ of the predicted aerosol mass over the AS during the Etesians is associated with the transport of aerosols and their precursors from outside the PMCAMx modelling domain. In the case of organics, this mass originates primarily from the oxidation of isoprene. These findings underline the significance of the detailed gaseous and aerosol model coupling developed in this study, towards more accurate model predictions. The origin of the transported plume during NW winds, distinctively identified from the model simulations (Greek industrialized areas) and the daily evolution of sulfate, $\mathrm{EC}$ (and OC / EC) and total $\mathrm{PM}_{10}$, shapes half of the total sulfate mass, the rest being attributed to the exogenous sources. Also, the observed peak in submicron sulfate during this event at Finokalia $\left(10 \mu \mathrm{g} \mathrm{m}^{-3}\right)$ is lower than the concentrations during the Etesian flow (12 to $14 \mathrm{\mu g} \mathrm{m}^{-3}$ ). Therefore, developing abatement strategies to reduce aerosol levels in the EM is both a national and transnational task. Key findings from the current and similar applications can provide information on the origin of air parcels and the contribution of local and exogenous sources, thus on the effective design of air policies.

A forthcoming application of the same model system aims at investigating its performance, as well as aerosol levels and interactions during recent Saharan dust intrusions in the troposphere over the Aegean Sea.

\section{The Supplement related to this article is available online at doi:10.5194/acp-15-8401-2015-supplement.}

Acknowledgements. This work is in the frame of the AERAS-EtS research project, which is implemented within the framework of the Action "Supporting Postdoctoral Researchers" of the Operational Program "Education and Lifelong Learning" (Action's Beneficiary: General Secretariat for Research and Technology), and is cofinanced by the European Social Fund (ESF) and the Greek state. Experimental data are available from: the AEGEAN-GAME-2 and ACEMED campaigns funded by EUFAR under FP7, the CarbonExp campaign funded by ESA and the CIMS project funded by the NERC campaign. Airborne data were obtained using the BAe-146-301 Atmospheric Research Aircraft flown by Directflight Ltd and managed by the Facility for Airborne Atmospheric Measurements (FAAM), which is a joint entity of NERC and the Met Office. We gratefully acknowledge the FAAM Team, M. Smith, A. Wellpott and A. Dean for all their effort to make campaigns successful. Many thanks to P. Brown and to the mission scientists D. Kindred and S. Abel, as well as the lidar person J. Kent, all from the Met. Office. E. Athanasopoulou thanks C. Fountoukis and S. N. Pandis for the use of the updated PMCAMx code, as well as V. Amiridis, D. Schuettemeyer and C. Percival for the use of the AMS data from the ACEMED, CarbonExp and CIMS flights. We greatly appreciate the constructive and helpful suggestions made by the two anonymous reviewers, which led us to important improvements in the manuscript.

Edited by: X. Querol 


\section{References}

Anagnostopoulou, C., Zanis, P., Katragkou, E., Tegoulias, I., and Tolika, K.: Recent past and future patterns of the Etesian winds based on regional scale climate model simulations, Clim. Dynam., 42, 1819-1836, doi:10.1007/s00382-013-1936-0, 2014.

Astitha, M. and Kallos, C.: Gas-phase and aerosol chemistry interactions in South Europe and the Mediterranean región, Environ. Fluid Mech., 9, 3-22, doi:10.1007/s10652-008-9110-7, 2008.

Athanasopoulou, E., Tombrou, M., Pandis, S. N., and Russell, A. G.: The role of sea-salt emissions and heterogeneous chemistry in the air quality of polluted coastal areas, Atmos. Chem. Phys., 8, 5755-5769, doi:10.5194/acp-8-5755-2008, 2008.

Athanasopoulou, E., Tombrou, M., Russell, A. G., Karanasiou, A., Eleftheriadis, K., and Dandou, A.: Implementation of road and soil dust emission parameterizations in the aerosol model CAMx: Applications over the greater Athens urban area affected by natural sources, J. Geophys. Res.-Atmos., 115, D17301, doi:10.1029/2009JD013207, 2010.

Athanasopoulou, E., Vogel, H., Vogel, B., Tsimpidi, A. P., Pandis, S. N., Knote, C., and Fountoukis, C.: Modeling the meteorological and chemical effects of secondary organic aerosols during an EUCAARI campaign, Atmos. Chem. Phys., 13, 625-645, doi:10.5194/acp-13-625-2013, 2013.

Bahreini, R., Ervens, B., Middlebrook, A. M., Warneke, C., de Gouw, J. A., DeCarlo, P. F., Jimenez, J. L., Brock, C. A., Neuman, J. A., Ryerson, T. B., Stark, H., Atlas, E., Brioude, J., Fried, A., Holloway, J. S., Peischl, J., Richter, D., Walega, J., Weibring, P., Wollny, A. G., and Fehsenfeld, F. C.: Organic aerosol formation in urban and industrial plumes near Houston and Dallas, Texas, J. Geophys. Res., 114, D00F16, doi:10.1029/2008JD011493, 2009.

Bardouki, H., Berresheim, H., Vrekoussis, M., Sciare, J., Kouvarakis, G., Oikonomou, K., Schneider, J., and Mihalopoulos, N.: Gaseous (DMS, MSA, $\mathrm{SO}_{2}, \mathrm{H}_{2} \mathrm{SO}_{4}$ and DMSO) and particulate (sulfate and methanesulfonate) sulfur species over the northeastern coast of Crete, Atmos. Chem. Phys., 3, 1871-1886, doi:10.5194/acp-3-1871-2003, 2003.

Benkovitz, C. M., Scholtz, M. T., Pacyna, J., Tarrason, L., Dignon, J., Voldner, E. C., Spiro, P. A., Logan, J. A., and Graedel, T. E.: Global gridded inventories of anthropogenic emissions of sulfur and nitrogen, J. Geophys. Res., 101, 29239-29253, 1996.

Bey, I., Jacob, D. J., Yantosca, R. M., Logan, J. A., Field, B. D., Fiore, A. M., Li, Q., Liu, H. Y., Mickley, L. J., and Schultz, M. G.: Global modeling of tropospheric chemistry with assimilated meteorology: Model description and evaluation, J. Geophys. Res., 106, 23073-23095, doi:10.1029/2001JD000807, 2001.

Bezantakos, S., Barmpounis, K., Giamarelou, M., Bossioli, E., Tombrou, M., Mihalopoulos, N., Eleftheriadis, K., Kalogiros, J., D. Allan, J., Bacak, A., Percival, C. J., Coe, H., and Biskos, G.: Chemical composition and hygroscopic properties of aerosol particles over the Aegean Sea, Atmos. Chem. Phys., 13, 1159511608, doi:10.5194/acp-13-11595-2013, 2013.

Bossioli, E., Tombrou, M., Kalogiros, J., Allan, J., Bacak, A., Bezantakos, S., Biskos, G., Coe, H., Jones, B. T., Kouvarakis, G. N., Mihalopoulos, N., and Percival, C. J.: Simulation of physical and chemical processes of polluted air masses during the Aegean-Game airborne campaign using WRF-Chem model, C O M E C A P 2014 e-book of proceedings, ISBN: 978-960-524430-9, Vol. 1, 155 pp., 2014.
Bougeault, P. and Lacarrère, P.: Parameterization of OrographyInduced Turbulence in a Mesobeta-Scale Model, Mon. Weather Rev., 117, 1872-1890, doi:10.1175/15200493(1989)117<1872:POOITI>2.0.CO;2, 1989.

Bougiatioti, A., Stavroulas, I., Kostenidou, E., Zarmpas, P., Theodosi, C., Kouvarakis, G., Canonaco, F., Prévôt, A. S. H., Nenes, A., Pandis, S. N., and Mihalopoulos, N.: Processing of biomassburning aerosol in the eastern Mediterranean during summertime, Atmos. Chem. Phys., 14, 4793-4807, doi:10.5194/acp-144793-2014, 2014.

Boylan, J. W. and Russell, A. G.: PM and light extinction model performance metrics, goals, and criteria for three-dimensional air quality models, Atmospheric Environment, 40(26), 4946-4959, doi:10.1016/j.atmosenv.2005.09.087, 2006.

Bryant, C., Eleftheriadis, K., Smolik, J., Zdimal, V., Mihalopoulos, N., and Colbeck, I.: Optical properties of aerosols over the eastern Mediterranean, Atmos. Environ., 40, 6229-6244, doi:10.1016/j.atmosenv.2005.06.009, 2006.

Canagaratna, M. R., Jayne, J. T., Jimenez, J. L., Allan, J. D., Alfarra, M. R., Zhang, Q., Onasch, T. B., Drewnick, F., Coe, H., Middlebrook, A., Delia, A., Williams, L. R., Trimborn, A. M., Northway, M. J., DeCarlo, P. F., Kolb, C. E., Davidovits, P., and Worsnop, D. R.: Chemical and microphysical characterization of ambient aerosols with the aerodyne aerosol mass spectrometer, Mass Spectrom. Rev., 26, 185-222, doi:10.1002/mas.20115, 2007.

Carter, W. P. L.: A detailed mechanism for the gas-phase atmospheric reactions of organic compounds, Atmos. Environ. Pt. A, 24, 481-518, doi:10.1016/0960-1686(90)90005-8, 1990.

Cavalli, F., Viana, M., Yttri, K. E., Genberg, J., and Putaud, J.-P.: Toward a standardised thermal-optical protocol for measuring atmospheric organic and elemental carbon: the EUSAAR protocol, Atmos. Meas. Tech., 3, 79-89, doi:10.5194/amt-3-79-2010, 2010.

Chabas, A. and Lefèvre, R. A.: Chemistry and microscopy of atmospheric particulates at Delos (Cyclades-Greece), Atmos. Environ., 34, 225-238, doi:10.1016/S1352-2310(99)00255-1, 2000.

Chung, S. H. and Seinfeld, J. H.: Global distribution and climate forcing of carbonaceous 9 aerosols, J. Geophys. Res., 107, 4407, doi:10.1029/2001JD001397, 2002.

Dandou, A., Tombrou, M., Kalogiros, J., Bossioli, E., Bezantakos, S., Biskos, G., Kouvarakis, G. N., Mihalopoulos, N., Allan, J., and Coe, H.: Simulation of Marine Boundary Layer Evolution in the Aegean Sea during Etesians, COMECAP2014 e-book of proceedings, ISBN: 978-960-524-430-9, Vol. 1, 220-224, 2014.

Donahue, N. M., Epstein, S. A., Pandis, S. N., and Robinson, A. L.: A two-dimensional volatility basis set: 1 . organic-aerosol mixing thermodynamics, Atmos. Chem. Phys., 11, 3303-3318, doi:10.5194/acp-11-3303-2011, 2011.

Eleftheriadis, K., Colbeck, I., Housiadas, C., Lazaridis, M., Mihalopoulos, N., Mitsakou, C., Smolík, J., and Ždímal, V.: Size distribution, composition and origin of the submicron aerosol in the marine boundary layer during the eastern Mediterranean "SUB-AERO" experiment, Atmos. Environ., 40, 6245-6260, doi:10.1016/j.atmosenv.2006.03.059, 2006.

Emery, C., Tai, E., and Yarwood, G.: Enhanced meteorological modeling and performance evaluation for two Texas Ozone Episodes, Report to the Texas Natural Resources Conservation 
Commission, prepared by ENVIRON, International Corp., Novato, CA, 2001

ENVIRON: International Corporation: User's Guide Comprehensive Air Quality Model with Extensions (CAMx) Version 4.00. ENVIRON International Corporation, Novato, California, available at: www.camx.com (last access: 8 January 2004), June 2003.

ENVIRON: User's Guide to the Comprehensive Air Quality Model with Extensions (CAMx), Version 5.40, Report prepared by ENVIRON International Corporation Novato, CA, available at: www.camx.com (last access: 5 June 2013), 2011.

Favez, O., Cachier, H., Sciare, J., Alfaro, S. C., El-Arabyc, T. M., Harhashd, M. A., and Abdelwahabd, M. M.: Seasonality of major aerosol species and their transformations in Cairo megacity, Atmos. Environ., 42 1503-1516, 2008.

Formenti, P., Reiner, T., Sprung, D., Andreae, M., Wendisch, M., Wex, H., Kindred, D., Dewey, K., Kent, J., Tzortziou, M., Vasaras, A., and Zerefos, C.: STAAARTE-MED 1998 summer airborne measurements over the Aegean Sea, 1, Aerosol particles and trace gases, J. Geophys. Res., 107, 4450, doi:10.1029/2001JD001337, 2002.

Fountoukis, C. and Nenes, A.: ISORROPIA II: a computationally efficient thermodynamic equilibrium model for $\mathrm{K}^{+}-\mathrm{Ca}^{2+}$ $\mathrm{Mg}^{2+}-\mathrm{NH}_{4}^{+}-\mathrm{Na}^{+}-\mathrm{SO}_{4}{ }^{2-}-\mathrm{NO}_{3}--\mathrm{Cl}_{-}-\mathrm{H}_{2} \mathrm{O}$ aerosols, Atmos. Chem. Phys., 7, 4639-4659, doi:10.5194/acp-7-4639-2007, 2007.

Fountoukis, C., Racherla, P. N., Denier van der Gon, H. A. C., Polymeneas, P., Charalampidis, P. E., Pilinis, C., Wiedensohler, A., Dall'Osto, M., O'Dowd, C., and Pandis, S. N.: Evaluation of a three-dimensional chemical transport model (PMCAMx) in the European domain during the EUCAARI May 2008 campaign, Atmos. Chem. Phys., 11, 10331-10347, doi:10.5194/acp11-10331-2011, 2011.

Fountoukis, C., Megaritis, A. G., Skyllakou, K., Charalampidis, P. E., Pilinis, C., Denier van der Gon, H. A. C., Crippa, M., Canonaco, F., Mohr, C., Prévôt, A. S. H., Allan, J. D., Poulain, L., Petäjä, T., Tiitta, P., Carbone, S., Kiendler-Scharr, A., Nemitz, E., O’Dowd, C., Swietlicki, E., and Pandis, S. N.: Organic aerosol concentration and composition over Europe: insights from comparison of regional model predictions with aerosol mass spectrometer factor analysis, Atmos. Chem. Phys., 14, 9061-9076, doi:10.5194/acp-14-9061-2014, 2014.

Gerasopoulos, E., Kouvarakis, G., Babasakalis, P., Vrekoussis, M., Putaud, J.-P., and Mihalopoulos, N.: Origin and variability of particulate matter (PM10) mass concentrations over the Eastern Mediterranean, Atmos. Environ., 40, 4679-4690, doi:10.1016/j.atmosenv.2006.04.020, 2006.

Gerasopoulos, E., Koulouri, E., Kalivitis, N., Kouvarakis, G., Saarikoski, S., Mäkelä, T., Hillamo, R., and Mihalopoulos, N.: Size-segregated mass distributions of aerosols over Eastern Mediterranean: seasonal variability and comparison with AERONET columnar size-distributions, Atmos. Chem. Phys., 7, 2551-2561, doi:10.5194/acp-7-2551-2007, 2007.

Heald, C. L., Coe, H., Jimenez, J. L., Weber, R. J., Bahreini, R., Middlebrook, A. M., Russell, L. M., Jolleys, M., Fu, T.-M., Allan, J. D., Bower, K. N., Capes, G., Crosier, J., Morgan, W. T., Robinson, N. H., Williams, P. I., Cubison, M. J., DeCarlo, P. F., and Dunlea, E. J.: Exploring the vertical profile of atmospheric organic aerosol: comparing 17 aircraft field campaigns with a global model, Atmos. Chem. Phys., 11, 12673-12696, doi:10.5194/acp-11-12673-2011, 2011.

Henze, D. K., Seinfeld, J. H., Ng, N. L., Kroll, J. H., Fu, T.-M., Jacob, D. J., and Heald, C. L.: Global modeling of secondary organic aerosol formation from aromatic hydrocarbons: highvs. low-yield pathways, Atmos. Chem. Phys., 8, 2405-2420, doi:10.5194/acp-8-2405-2008, 2008.

Hildebrandt, L., Kostenidou, E., Mihalopoulos, N., Worsnop, D. R., Donahue, N. M., and Pandis, S. N.: Formation of highly oxygenated organic aerosol in the atmosphere: Insights from the Finokalia Aerosol Measurement Experiments, Geophys. Res. Lett., 37, L23801, doi:10.1029/2010GL045193, 2010.

Hong, S.-Y., Noh, Y., and Dudhia, J.: A new vertical diffusion package with an explicit 29 treatment of entrainment processes, Mon. Weather Rev., 134, 2318-2341, 2006.

Im, U.: Impact of sea-salt emissions on the model performance and aerosol chemical composition and deposition in the East Mediterranean coastal regions, Atmos. Environ., 75, 329-340, doi:10.1016/j.atmosenv.2013.04.034, 2013.

Im, U. and Kanakidou, M.: Impacts of East Mediterranean megacity emissions on air quality, Atmos. Chem. Phys., 12, 6335-6355, doi:10.5194/acp-12-6335-2012, 2012.

Im, U., Markakis, K., Koçak, M., Gerasopoulos, E., Daskalakis, N., Mihalopoulos, N., Poupkou, A., Kindap, T., Unal, A., and Kanakidou, M.: Summertime aerosol chemical composition in the Eastern Mediterranean and its sensitivity to temperature, Atmos. Environ., 50, 164-173, doi:10.1016/j.atmosenv.2011.12.044, 2012.

Kallos, G., Astitha, M., Katsafados, P., and Spyrou, C.: Long-Range Transport of Anthropogenically and Naturally Produced Particulate Matter in the Mediterranean and North Atlantic: Current State of Knowledge, J. Appl. Meteor. Climatol., 46, 1230-1251, doi:10.1175/JAM2530.1, 2007.

Kallos, G., Solomos, S., Kushta, J., Mitsakou, C., Spyrou, C., Bartsotas, N., and Kalogeri, C.: Natural and anthropogenic aerosols in the Eastern Mediterranean and Middle East: Possible impacts, Sci. Total Environ., 488-489, 389-397, doi:10.1016/j.scitotenv.2014.02.035, 2014.

Kanakidou, M., Mihalopoulos, N., Kindap, T., Im, U., Vrekoussis, M., Gerasopoulos, E., Dermitzaki, E., Unal, A., Koçak, M. Markakis, K., Melas, D., Kouvarakis, G., Youssef, A. F., Richter, A., Hatzianastassiou, N., Hilboll, A., Ebojie, F., Wittrock, F., von Savigny, C., Burrows, J. P., Ladstaetter-Weissenmayer, A., and Moubasher, H.: Megacities as hot spots of air pollution in the East Mediterranean, Atmos. Environ., 45, 1223-1235, doi:10.1016/j.atmosenv.2010.11.048, 2011.

Kandler, K., Benker, N., Bundke, U., Cuevas, E., Ebert, M., Knippertz, P., Rodríguez, S., Schütz, L., and Weinbruch, S.: Chemical composition and complex refractive index of Saharan Mineral Dust at Izaña, Tenerife (Spain) derived by electron microscopy, Atmos. Environ., 41, 8058-8074, doi:10.1016/j.atmosenv.2007.06.047, 2007.

Kopanakis, I., Eleftheriadis, K., Mihalopoulos, N., LydakisSimantiris, N., Katsivela, E., Pentari, D., Zarmpas, P., and Lazaridis, M.: Physico-chemical characteristics of particulate matter in the Eastern Mediterranean, Atmos. Res., 106, 93-107, doi:10.1016/j.atmosres.2011.11.011, 2012.

Kotroni, V., Lagouvardos, K., and Lalas, D.: The effect of the island of Crete on the Etesian winds over the Aegean Sea, Q. J. R. 
Meteorol. Soc., 127, 1917-1937, doi:10.1002/qj.49712757604, 2001.

Koulouri, E., Saarikoski, S., Theodosi, C., Markaki, Z., Gerasopoulos, E., Kouvarakis, G., Mäkelä, T., Hillamo, R., and Mihalopoulos, N.: Chemical composition and sources of fine and coarse aerosol particles in the Eastern Mediterranean, Atmos. Environ., 42, 6542-6550, doi:10.1016/j.atmosenv.2008.04.010, 2008.

Kouvarakis, G., Mihalopoulos, N., Tselepides, A., and Stavrakakis, S.: On the importance of atmospheric inputs of inorganic nitrogen species on the productivity of the Eastern Mediterranean Sea, Global Biogeochem. Cy., 15, 805-817, doi:10.1029/2001GB001399, 2001.

Lane, T. E., Donahue, N. M., and Pandis, S. N.: Simulating secondary organic aerosol formation using the volatility basis-set approach in a chemical transport model, Atmos. Environ., 42, 7439-7451, doi:10.1016/j.atmosenv.2008.06.026, 2008.

Lazaridis, M., Spyridaki, A., Solberg, S., Smolík, J., Zdímal, V., Eleftheriadis, K., Aleksanropoulou, V., Hov, O., and Georgopoulos, P. G.: Mesoscale modeling of combined aerosol and photooxidant processes in the Eastern Mediterranean, Atmos. Chem. Phys., 5, 927-940, doi:10.5194/acp-5-927-2005, 2005.

Lazaridis, M., Dzumbova, L., Kopanakis, I., Ondracek, J., Glytsos, T., Aleksandropoulou, V., Voulgarakis, A., Katsivela, E., Mihalopoulos, N., and Eleftheriadis, K.: PM10 and PM2.5 Levels in the Eastern Mediterranean (Akrotiri Research Station, Crete, Greece), Water Air Soil Pollut., 189, 85-101, doi:10.1007/s11270-007-9558-y, 2008.

Maheras, P.: Le problem des Etesiens, Mediterranee, 40, 57-66, 1986.

Mailler, S., Khvorostyanov, D., and Menut, L.: Impact of the vertical emission profiles on background gas-phase pollution simulated from the EMEP emissions over Europe, Atmos. Chem. Phys., 13, 5987-5998, doi:10.5194/acp-13-5987-2013, 2013.

Medina, S., Plasencia, A., Ballester, F., Mucke, H. G., and Schwartz, J.: 'Apheis: Public Health Impact of PM10 in 19 European Cities', J. Epidemiol. Community Health, 58, 831-836, 2004.

Megaritis, A. G., Fountoukis, C., Charalampidis, P. E., Pilinis, C., and Pandis, S. N.: Response of fine particulate matter concentrations to changes of emissions and temperature in Europe, Atmos. Chem. Phys., 13, 3423-3443, doi:10.5194/acp-13-34232013, 2013.

Metzger, S., Mihalopoulos, N., and Lelieveld, J.: Importance of mineral cations and organics in gas-aerosol partitioning of reactive nitrogen compounds: case study based on MINOS results, Atmos. Chem. Phys., 6, 2549-2567, doi:10.5194/acp-6-25492006, 2006.

Middlebrook, A. M., Bahreini, R., Jimenez, J. L., and Canagaratna, M. R.: Evaluation of composition-dependent collection efficiencies for the Aerodyne Aerosol Mass Spectrometer using field data, Aerosol Sci. Technol., 46, 258-271, doi:10.1080/02786826.2011.620041, 2012.

Mihalopoulos, N., Stephanou, E., Kanakidou, M., Pilitsidis, S., and Bousquet, P.: Tropospheric aerosol ionic composition in the Eastern Mediterranean region, Tellus B, 49, doi:10.3402/tellusb.v49i3.15970, 1997.

Mihalopoulos, N., Kerminen, V. M., Kanakidou, M., Berresheim, H., and Sciare, J.: Formation of particulate sulfur species (sulfate and methanesulfonate) during summer over the Eastern Mediter- ranean: A modelling approach, Atmos. Environ., 41, 6860-6871, doi:10.1016/j.atmosenv.2007.04.039, 2007.

Millán, M. M., Salvador, R., Mantilla, E., and Kallos, G.: Photooxidant dynamics in the Mediterranean basin in summer: Results from European research projects, J. Geophys. Res.-Atmos., 102, 8811-8823, 1997.

Morgan, W. T., Allan, J. D., Bower, K. N., Highwood, E. J., Liu, D., McMeeking, G. R., Northway, M. J., Williams, P. I., Krejci, R., and Coe, H.: Airborne measurements of the spatial distribution of aerosol chemical composition across Europe and evolution of the organic fraction, Atmos. Chem. Phys., 10, 4065-4083, doi:10.5194/acp-10-4065-2010, 2010.

Murphy, B. N., Donahue, N. M., Fountoukis, C., and Pandis, S. N.: Simulating the oxygen content of ambient organic aerosol with the 2D volatility basis set, Atmos. Chem. Phys., 11, 7859-7873, doi:10.5194/acp-11-7859-2011, 2011.

Nabat, P., Somot, S., Mallet, M., Sevault, F., Chiacchio, M., and Wild, M.: Direct and semi-direct aerosol radiative effect on the Mediterranean climate variability using a coupled regional climate system model, Clim. Dynam., 44, 1127-1155, 1-29, doi:10.1007/s00382-014-2205-6, 2014.

Nopmongcol, U., Koo, B., Tai, E., Jung, J., Piyachaturawat, P., Emery, C., Yarwood, G., Pirovano, G., Mitsakou, C., and Kallos, G.: Modeling Europe with CAMx for the Air Quality Model Evaluation International Initiative (AQMEII), Atmos. Environ. 53, 177-185, doi:10.1016/j.atmosenv.2011.11.023, 2012.

Orsini, D. A., Ma, Y., Sullivan, A., Sierau, B., Baumann, K., and Weber, R. J.: Refinements to the particle-into-liquid sampler (PILS) for ground and airborne measurements of water-soluble aerosol composition, Atmos. Environ., 37, 1243-1259, 2003

Paraskevopoulou, D., Liakakou, E., Gerasopoulos, E., Theodosi, C., and Mihalopoulos, N.: Long-term characterization of organic and elemental carbon in the $\mathrm{PM}_{2.5}$ fraction: the case of Athens, Greece, Atmos. Chem. Phys., 14, 13313-13325, doi:10.5194/acp-14-13313-2014, 2014.

Pey, J., Alastuey, A., and Querol, X.: PM10 and PM2.5 sources at an insular location in the western Mediterranean by using source apportionment techniques, Sci. Total Environ., 456-457, 267-277, doi:10.1016/j.scitotenv.2013.03.084, 2013a.

Piccot, S. D., Watson, J. J., and Jones, J. W.: A global inventory of volatile organic compound emissions from anthropogenic sources, J. Geophys. Res., 97, 9897-9912, 1992.

Pikridas, M., Bougiatioti, A., Hildebrandt, L., Engelhart, G. J., Kostenidou, E., Mohr, C., Prévôt, A. S. H., Kouvarakis, G., Zarmpas, P., Burkhart, J. F., Lee, B.-H., Psichoudaki, M., Mihalopoulos, N., Pilinis, C., Stohl, A., Baltensperger, U., Kulmala, M., and Pandis, S. N.: The Finokalia Aerosol Measurement Experiment - 2008 (FAME-08): an overview, Atmos. Chem. Phys., 10, 6793-6806, doi:10.5194/acp-10-6793-2010, 2010.

Price, C. and Rind, D.: A Simple lightning parameterization for calculating global lightning 18 distributions, J. Geophys. Res., 97, 9919-9933, doi:10.1029/92JD00719, 1992.

Rodríguez, S., Querol, X., Alastuey, A., Kallos, G. and Kakaliagou, O.: Saharan dust contributions to PM10 and TSP levels in Southern and Eastern Spain, Atmos. Environ., 35, 2433-2447, doi:10.1016/S1352-2310(00)00496-9, 2001.

Rodríguez, S., Querol, X., Alastuey, A., and Plana, F.: Sources and processes affecting levels and composition of atmospheric 
aerosol in the western Mediterranean, J.-Geophys.-Res., 107, 4777, doi:10.1029/2001JD001488, 2002.

Sciare, J., Bardouki, H., Moulin, C., and Mihalopoulos, N.: Aerosol sources and their contribution to the chemical composition of aerosols in the Eastern Mediterranean Sea during summertime, Atmos. Chem. Phys., 3, 291-302, doi:10.5194/acp-3-291-2003, 2003a.

Sciare, J., Cachier, H., Oikonomou, K., Ausset, P., Sarda-Estève, R., and Mihalopoulos, N.: Characterization of carbonaceous aerosols during the MINOS campaign in Crete, July-August 2001: a multi-analytical approach, Atmos. Chem. Phys., 3, 17431757, doi:10.5194/acp-3-1743-2003, 2003b.

Sciare, J., Oikonomou, K., Cachier, H., Mihalopoulos, N., Andreae, M. O., Maenhaut, W., and Sarda-Estève, R.: Aerosol mass closure and reconstruction of the light scattering coefficient over the Eastern Mediterranean Sea during the MINOS campaign, Atmos. Chem. Phys., 5, 2253-2265, doi:10.5194/acp-5-2253-2005, 2005.

Sciare, J., Oikonomou, K., Favez, O., Liakakou, E., Markaki, Z., Cachier, H., and Mihalopoulos, N.: Long-term measurements of carbonaceous aerosols in the Eastern Mediterranean: evidence of long-range transport of biomass burning, Atmos. Chem. Phys., 8, 5551-5563, doi:10.5194/acp-8-5551-2008, 2008.

Sciare, J., d' Argouges, O., Sarda-Estève, R., Gaimoz, C., Dolgorouky, C., Bonnaire, N., Favez, O., Bonsang, B., and Gros, V.: Large contribution of water-insoluble secondary organic aerosols in the region of Paris (France) during wintertime, J. Geophys. Res., 116, D22203, doi:10.1029/2011JD015756, 2011.

Shrivastava, M. K., Lane, T. E., Donahue, N. M., Pandis, S. N., and Robinson, A. L.: Effects of gas particle partitioning and aging of primary emissions on urban and regional organic aerosol concentrations, J. Geophys. Res., 113, D18301, doi:10.1029/2007JD009735, 2008.

Skamarock, W. C., Klemp, J. B., Dudhia, J., Gill, D. O., Barker, D. M., Wang, W., and Powers, J. G.: A Description of the Advanced Research WRF Version 3, NCAR Technical Note TN468+STR., 113 pp., 2008.

Skjøth, C. A., Geels, C., Berge, H., Gyldenkærne, S., Fagerli, H., Ellermann, T., Frohn, L. M., Christensen, J., Hansen, K. M., Hansen, K., and Hertel, O.: Spatial and temporal variations in ammonia emissions - a freely accessible model code for Europe, Atmos. Chem. Phys., 11, 5221-5236, doi:10.5194/acp-11-52212011, 2011.

Smolík, J., Ždímal, V., Schwarz, J., Lazaridis, M., Havárnek, V., Eleftheriadis, K., Mihalopoulos, N., Bryant, C., and Colbeck, I.: Size resolved mass concentration and elemental composition of atmospheric aerosols over the Eastern Mediterranean area, Atmos. Chem. Phys., 3, 2207-2216, doi:10.5194/acp-3-2207-2003, 2003.

Solomos, S., Kallos, G., Kushta, J., Astitha, M., Tremback, C., Nenes, A., and Levin, Z.: An integrated modeling study on the effects of mineral dust and sea salt particles on clouds and precipitation, Atmos. Chem. Phys., 11, 873-892, doi:10.5194/acp11-873-2011, 2011.

Sukoriansky, S., Galperin, B., and Staroselsky, I.: A quasinormal scale elimination model of turbulent flows with stable stratification, Phys. Fluids, 17, 085107, doi:10.1063/1.2009010, 2005.

Tesche, T. W., McNally, D. E., Emery, C. A., and Tai, E.: Evaluation of the MM5 model over the Midwestern U.S. for three 8-hr oxidant episodes. Prepared for the Kansas City Ozone Technical Work Group, prepared by Alpine Geophysics, LLC, Ft. Wright, KY and ENVIRON International Corp., Novato, CA, 2001.

Theodosi, C., Im, U., Bougiatioti, A., Zarmpas, P., Yenigun, O., and Mihalopoulos, N.: Aerosol chemical composition over Istanbul, Sci. Total Environ., 408, 2482-2491, doi:10.1016/j.scitotenv.2010.02.039, 2010.

Tombrou, M., Bossioli, E., Protonotariou, A. P., Flocas, H., Giannakopoulos, C., and Dandou, A.: Coupling GEOS-CHEM with a regional air pollution model for Greece, Atmos. Environ., 43, 4793-4804, doi:10.1016/j.atmosenv.2009.04.003, 2009

Tombrou, M., Bossioli, E., Kalogiros, Y., Allan, J., Bacak, A., Biskos, G., Coe, H., Dandou, A., Kouvarakis, G., Mihalopoulos, N., Protonotariou, A. P., Szabó-Takács, B., and Triantafillou, E.: Physical and Chemical Processes of Polluted Air Masses During Etesians: Aegean-Game Airborne Campaign - An Outline, Atmos. Sci., 3, 1239-1244, doi:10.1007/978-3-642-29172-2_173, 2013.

Tombrou, M., Bossioli, E., Kalogiros, J., Allan, J. D., Bacak, A., Biskos, G., Coe, H., Dandou, A., Kouvarakis, G., Mihalopoulos, N., Percival, C. J., Protonotariou, A. P., and Szabó-Takács, B.: Physical and chemical processes of air masses in the Aegean Sea during Etesians: Aegean-GAME airborne campaign, Sci. Total Environ., 506-507, 201-216, doi:10.1016/j.scitotenv.2014.10.098, 2015.

Tsimpidi, A. P., Karydis, V. A., Zavala, M., Lei, W., Molina, L., Ulbrich, I. M., Jimenez, J. L., and Pandis, S. N.: Evaluation of the volatility basis-set approach for the simulation of organic aerosol formation in the Mexico City metropolitan area, Atmos. Chem. Phys., 10, 525-546, doi:10.5194/acp-10-525-2010, 2010.

Turpin, B. J. and Lim, H.-J.: Species Contributions to PM2.5 Mass Concentrations: Revisiting Common Assumptions for Estimating Organic Mass, Aerosol Sci. Technol., 35, 602-610, doi:10.1080/02786820119445, 2001.

Tyrlis, E. and Lelieveld, J.: Climatology and Dynamics of the Summer Etesian Winds over the Eastern Mediterranean, J. Atmos. Sci., 70, 3374-3396, doi:10.1175/JAS-D-13-035.1, 2013.

Vrekoussis, M., Liakakou, E., Koçak, M., Kubilay, N., Oikonomou, K., Sciare, J., and Mihalopoulos, N.: Seasonal variability of optical properties of aerosols in the Eastern Mediterranean, Atmos. Environ., 39, 7083-7094, doi:10.1016/j.atmosenv.2005.08.011, 2005.

Wang, Y., Jacob, D. J., and Logan, J. A.: Global simulation of tropospheric O3-NOx-hydrocarbon chemistry, 1. Model formulation, J. Geophys. Res., 103, 10713-10726, 1998.

Yevich, R. and Logan, J. A.: An assessment of biofuel use and burning of agricultural waste 16 in the developing world, Global Biogeochem. Cy., 17, 1095, doi:10.1029/2002GB001952, 2003.

Zhang, H., Chen, G., Hu, J., Chen, S.-H., Wiedinmyer, C., Kleeman, M., and Ying, Q.: Evaluation of a seven-year air quality simulation using the Weather Research and Forecasting (WRF)/Community Multiscale Air Quality (CMAQ) models in the eastern United States, Sci. Total Environ., 473-474, 275-285, doi:10.1016/j.scitotenv.2013.11.121, 2014. 